\title{
Modulation of Immune Responses to Influenza A Virus Vaccines by Natural Killer T Cells
}

\author{
John P. Driver ${ }^{1}$, Darling Melany de Carvalho Madrid ${ }^{1}$, Weihong Gu ${ }^{1}$, Bianca L. Artiaga ${ }^{2}$ \\ and Jürgen A. Richt ${ }^{2 *}$
}

${ }^{1}$ Department of Animal Sciences, University of Florida, Gainesville, FL, United States, ${ }^{2}$ Diagnostic Medicine/Pathobiology, College of Veterinary Medicine, Kansas State University, Manhattan, KS, United States

Influenza A viruses (IAVs) circulate widely among different mammalian and avian hosts and sometimes give rise to zoonotic infections. Vaccination is a mainstay of IAV prevention and control. However, the efficacy of IAV vaccines is often suboptimal because of insufficient cross-protection among different IAV genotypes and subtypes as well as the inability to keep up with the rapid molecular evolution of IAV strains. Much attention is focused on improving IAV vaccine efficiency using adjuvants, which are substances that can modulate and enhance immune responses to co-administered antigens. The

OPEN ACCESS

Edited by:

Jordi Ochando,

Icahn School of Medicine at Mount

Sinai, United States

Reviewed by:

Mark L. Lang,

University of Oklahoma Health

Sciences Center, United States

Estanislao Nistal-Villan,

San Pablo CEU University, Spain

${ }^{*}$ Correspondence:

Jürgen A. Richt

jricht@ksu.edu

Specialty section:

This article was submitted to Vaccines and Molecular Therapeutics,

a section of the journal

Frontiers in Immunology

Received: 30 May 2020

Accepted: 10 August 2020

Published: 20 October 2020

Citation:

Driver JP, de Carvalho Madrid DM, Gu W, Artiaga BL and Richt JA (2020) Modulation of Immune Responses to Influenza A Virus Vaccines by Natura

Killer T Cells.

Front. Immunol. 11:2172.

doi: 10.3389/fimmu.2020.02172 current review is focused on a non-traditional approach of adjuvanting IAV vaccines by therapeutically targeting the immunomodulatory functions of a rare population of innatelike $T$ lymphocytes called invariant natural killer T (iNKT) cells. These cells bridge the innate and adaptive immune systems and are capable of stimulating a wide array of immune cells that enhance vaccine-mediated immune responses. Here we discuss the factors that influence the adjuvant effects of iNKT cells for influenza vaccines as well as the obstacles that must be overcome before this novel adjuvant approach can be considered for human or veterinary use.

Keywords: natural killer T (NKT) cells, influenza A virus, vaccines, immune modulation, adjuvant

\section{INTRODUCTION}

Influenza A viruses (IAVs) are a genetically diverse group of segmented RNA viruses capable of infecting birds and mammals, including swine, bats, and humans (1-3). IAV infections result in a highly contagious acute respiratory disease that is capable of causing substantial morbidity but usually low mortality $(4,5)$. IAVs are a significant burden to human and animal health and have the potential to occasionally cause pandemics. Vaccination is a cornerstone of IAV mitigation. However, the high genetic/antigenic diversity of IAVs, which is a result of (i) the rapid IAV mutation rates ("genetic drift") and (ii) the reassortment ability between genetically different IAV strains ("genetic shift"), inherently limits vaccine effectiveness (6). The genetic evolution of IAVs by genetic drift and shift associated with the heterogeneous and complex immune response to influenza vaccines requires annual updates of human IAV vaccines and often results in vaccine failure $(2,7)$. For example, the 2018-2019 influenza vaccines for humans were reported to have an estimated vaccine effectiveness of $29 \%$ (8), based on the relative difference in influenza risk between vaccinated and unvaccinated participants (9). This low effectiveness was due to the circulation of an influenza $\mathrm{H} 3 \mathrm{~N} 2$ virus which was antigenically drifted from the $\mathrm{H} 3 \mathrm{~N} 2$ virus isolate included in the vaccine (8). The use of adjuvants that increase the scope, scale, and quality of innate and adaptive 
immune responses can improve the effectiveness of IAV vaccines significantly (10). Most adjuvants fall into two categories. The first is delivery systems that enhance antigen release, stability, and uptake (11). The second uses immune stimulatory molecules, such as Toll-like receptor ligands, that induce the release of cytokines and chemokines from innate immune cells, which drives antigen-presenting cell (APC) maturation and licensing and, therefore, improves immunogenicity of the respective antigens (12).

Although conventional adjuvants can stimulate cellular and humoral immune responses and reduce the antigen dose required in the vaccine, they seldom improve long-term immunity and cross-reactivity against heterologous (i.e., belong to the same subtype but are genetically different IAV isolates) and heterosubtypic (i.e., belong to different IAV subtypes) IAV strains, which is greatly needed (13). This has led researchers to explore using non-traditional adjuvants to improve vaccine efficacy, including the powerful immunoregulatory effects of innate $\mathrm{T}$ lymphocyte populations, such as $\gamma \delta \mathrm{T}$ cells, and CD1and MR-1-resticted T cells. Unlike the major histocompatibility complex (MHC)-restricted $\mathrm{T}$ cells, these cells possess a restricted repertoire of $\mathrm{T}$ cell receptors (TCR), perform rapid effector responses, and recognize a limited selection of nonpeptide molecules, including small metabolites and lipids (14). Currently, the innate $\mathrm{T}$ cell population with the most potential to enhance vaccines is natural killer T (NKT) cells, which recognize lipid and glycolipid ligands presented by the MHC class I-like molecule CD1d (14). These cells have phenotypic characteristics of both $\mathrm{T}$ cells and NK cells and express a semi-invariant TCR (14). Upon activation, NKT cells rapidly release large quantities of multiple cytokines and chemokines capable of boosting adaptive immune responses. Importantly, a subset of NKT cells known as type I or invariant NKT (iNKT) cells that express an invariant $\alpha \beta$ TCR, can be globally and specifically activated using derivatives of the prototypic antigen known as $\quad(2 \mathrm{~S}, 3 \mathrm{~S}, 4 \mathrm{R})-1-\mathrm{O}-(\alpha-\mathrm{D}$-galactopyranosyl)-N-hexacosanoyl-2amino-1,3,4-octadecanetriol, also called $\alpha$-galactosylceramide ( $\alpha$-GalCer), which was first isolated from a marine sponge (Agelas mauritianus) $(15,16)$. Activation with $\alpha$-GalCer induces iNKT cells to generate a potent immune response to a wide range of co-delivered antigens.

Since the discovery of $\alpha$-GalCer, numerous studies have explored how iNKT cell responses can adjuvant vaccines against different infectious diseases [reviewed in (17-20)]. However, most of these studies have used the mouse model of IAV infection, largely because it is wellestablished and easy to work with. These studies have almost invariably reported that iNKT cells are capable of substantially enhancing the quality and the scale of IAV vaccine responses (21-33). In this review, we summarize the current knowledge about therapeutically harnessing iNKT cell activities to improve IAV vaccines in mice and other animal models. We also address important factors that influence the adjuvant effects of therapeutically activated iNKT cells, which must be considered to safely and effectively exploit the adjuvant potential of iNKT cells for human or livestock vaccines.

\section{NKT CELL CHARACTERISTICS}

Although the name "natural killer T cell" first appeared in the literature in 1995 (34), these cells were first described in 1987 as a subset of T cells with moderate levels of $\alpha \beta$ TCRs and NK1.1, a marker characteristic of natural killer cells (35-38). Over the subsequent decade, it was established that NKT cells express a highly restricted TCR repertoire (39), produce developmentally regulated Th1 and Th2 cytokines (40), bind CD1d as their antigen presenting molecule (41), and recognize glycolipid/lipid ligands $(15,42)$. It was further discovered that NKT cells can be divided into two functionally distinct classes: type I and type II NKT cells (43). Type I NKT or iNKT cells express a highly restricted TCR repertoire which recognizes CD1d-bound $\alpha$-GalCer $(44,45)$. Type II NKT cells, also known as diverse NKT cells, express a less restricted TCR repertoire and recognize different glycolipids than iNKT cells, such as sulfatides (46). This review will discuss iNKT cells as it is this subset which can be therapeutically targeted using glycolipid antigens.

iNKT cells recognize both endogenous and exogenous ligands (42). Their recognition of endogenous ligands enables iNKT cells to interact with inflamed or injured tissues which overexpress lipid molecules (47). Most exogenous iNKT cell antigens are glycolipid and phospholipid components of bacterial cell walls, such as mycobacterial phosphatidylinositolmannosides and monoglycosylceramides from gram-negative bacteria $(42,48)$. iNKT cells also respond to antigens from protozoan parasites, including phospholipids from Leishmania and glycophosphatidylinositol from Plasmodium and Trypanosoma $(49,50)$. iNKT cells in most species react to $\alpha$-GalCer and its synthetic analog KRN7000 (51-53). These molecules have been widely used to study iNKT cell function since they strongly activate these cells. $\alpha$-GalCer stimulated mouse iNKT cells produce a wide variety of cytokines, including IFN- $\gamma$, IL-2, IL-3, IL-4, IL-5, IL-9, IL-10, IL-13, IL-17, IL-21, IL-22, and tumor necrosis factor (TNF) $-\alpha$ and $-\beta$ (54-57). Stimulated mouse iNKT cells also secrete chemokines, including RANTES (regulated on activation, normal $\mathrm{T}$ cell expressed and secreted), monocyte chemoattractant protein (MCP)-1, eotaxins, and macrophage inflammatory protein (MIP)- $1 \alpha$ and MIP-1 $\beta$ (58-61). Many of these cytokines modulate cellular and humoral immune responses against foreign antigens, which is why $\alpha$-GalCer activated iNKT cells can enhance the scale and the scope of vaccine responses against a wide variety of pathogens.

\section{iNKT CELL-CD1d SYSTEM IN MAMMALS}

The defining feature of iNKT cells is the expression of a TCR with an invariant $\mathrm{V} \alpha$ chain rearrangement and limited $V \beta$ chain usage. Mouse iNKT cells express a single $\alpha$ chain $(\mathrm{V} \alpha 14-\mathrm{J} \alpha 18)$ that is paired with a limited number of $\mathrm{V} \beta$ chains $(\mathrm{V} \beta 2, \mathrm{~V} \beta 7$, or $\mathrm{V} \beta 8.2)$ $(39,62,63)$. Rats use a homologous $\mathrm{V} \alpha 14-\mathrm{J} \alpha 18$ rearrangement paired with V $\beta 8.2$ chains but have four V $\alpha 14$ genes with differential tissue expression (64). The human invariant receptor is composed of a V $\alpha 24-\mathrm{J} \alpha 18$ rearrangement paired with $\mathrm{V} \beta 11$ $(39,65,66)$, while the porcine iNKT TCR is composed of a $\mathrm{V} \alpha 10-\mathrm{J} \alpha 18$ chain paired with a V $\beta 25$-chain, both of which are 
highly homologous to the human V $\alpha 24-\mathrm{J} \alpha 18$ and V $\beta 11$ TCR chains (67). A consequence of the remarkably conserved nature of the TCR-CD1d system is that CD1d tetramers often crossreact among different animal species. For instance, human CD1d tetramers cross-react with mouse iNKT cells and vice versa (45), and both mouse and human CD1d tetramers cross-react with pig iNKT cells (68). Interestingly, rat iNKT cells are only partially identified by mouse CD1d tetramers and require the use of rat CD1d molecules in glycolipid-loaded tetramers (69). Overall, the CD1d-mediated recognition of $\alpha$-GalCer by iNKT cells is highly conserved through mammalian evolution (70). This has the advantage that many aspects of glycolipid therapy research in preclinical mouse models can be directly translated to target animal species, including humans.

Not all mammals harbor CD1d genes in their genomes, and some that do, do not express functional transcripts and/or CD1d proteins that are capable of interacting with iNKT cells. Humans (71), primates $(72,73)$, mice (15), rats (64), cotton rats (74), pigs $(75,76)$, and dogs $(77)$ have been reported to possess functional iNKT cell-CD1d systems and iNKT cells that react to $\alpha$-GalCer. Ruminants were thought to harbor two copies of CD1d that are pseudogenes (CD1d1 and CD1d2) due to a mutated start codon and a first intron that cannot be translated into functional proteins $(78,79)$. However, it was later discovered that the bovine CD1d1 gene has an alternative start codon that produces CD1d proteins capable of being expressed on the cell surface (80). Interestingly, the antigen binding site in bovine CD1d 1 is smaller than in human and mouse CD1d proteins, which prohibits $\alpha$ GalCer from binding. Instead, bovine CD1d1 appears to present glycolipids with shorter alkyl chains than $\alpha$-GalCer $(80,81)$. The sequences of the equine iNKT invariant $\alpha$-chain TCR and CD1d have conserved residues that align with their human and mouse counterparts. Nevertheless, equine iNKT cells have yet to be isolated and horses do not respond to synthetic glycolipids that activate iNKT cells in other species (82).

\section{MECHANISMS OF INKT CELL ACTIVATION}

iNKT cells can be directly activated by TCR signaling after engaging CD1d-bound glycolipid antigens, or indirectly via cytokines from pathogen recognition receptor-stimulated APCs. Indirect activation sometimes involves weak TCR signals from low-affinity microbial or self-lipid antigens but can also occur in the absence of TCR stimulation (83-88). Directly activated mouse iNKT cells secrete a mixture of Th1 and Th2 cytokines, which differs from iNKT cells indirectly activated through proinflammatory cytokines that mainly produce Th1-type cytokines $(89,90)$. The variety and the quantity of cytokines produced by directly activated iNKT cells depend on the strength of the interactions between the iNKT TCR and the lipid-CD1d complex $(43,83,91,92)$. However, additional factors, including different iNKT cell subsets, the half-life of TCR-ligand binding, ligand density, and the uptake and presentation of iNKT cellactivating glycolipids by APCs, may play a role in determining their cytokine bias (93-97). $\alpha$-GalCer strongly activates iNKT cells, which induces the rapid upregulation of $\mathrm{T}$ cell activation markers and the secretion of several cytokines, especially IFN- $\gamma$, IL-2, and IL-4 within hours after stimulation. $\alpha$-GalCer activated iNKT cells also proliferate and may expand up to 10 -fold in some organs by 4 days post-treatment, after which they contract to baseline levels $(98,99)$. Unlike conventional T cells, iNKT cells do not possess memory functions. In fact, secondary $\alpha$ GalCer administration actually results in a significantly weaker iNKT cell response compared to primary stimulation with this antigen, characterized by reduced proliferation and cytokine secretion $(100,101)$. This hyporesponsive state lasts for at least 1 month after initial activation (101-103). The same hyporesponsive state has been reported in mice challenged with bacterial pathogens (104-106), toxins (107), and TLR agonists (104). The response of iNKT cells to $\alpha$-GalCer have been studied most extensively in mice. However, in vivo studies in humans, chimpanzees, macaques, swine, and cotton rats have found that $\alpha$-GalCer can stimulate iNKT cell activities in a wide variety of mammals.

iNKT cells indirectly activated by APCs participate in immune responses against numerous microorganisms that lack cognate lipid antigens. Various pathogen-associated molecular patterns (PAMPs) and some danger-associated molecular patterns (DAMPs) have been shown to induce iNKT cell-activating cytokines (108-112), such as type I interferons, IL-12, IL-18, and IL-33 (88, 90, 113-115). Interleukin-12 signaling appears to be particularly important as iNKT cells express high baseline levels of the IL-12 receptor (116). Many bacterial and viral infections stimulate sufficient IL-12 to activate iNKT cells with low-affinity endogenous ligands or without TCR signaling $(88,89,113,117,118)$. Indirect iNKT cell activation may also be induced by IFN- $\alpha$ and IFN- $\beta$ from TLR-7- and TLR-9-activated APCs (113) or by a combination of IL-12 and IL-18, which are produced by TLR-4- and TLR-9-stimulated APCs $(88,90,114)$. iNKT cells can also be activated via their NK receptors that provide both activation and regulation signals in response to stress-induced ligands (119-121). Indirectly activated iNKT cells develop distinct effector functions compared to directly activated iNKT cells. One important difference is that a large fraction of cytokine-activated iNKT cells acquire the ability to express perforin that may allow them to carry out cytolytic functions in vivo (54). Furthermore, indirectly activated iNKT cells secrete large quantities of IFN- $\gamma$ without IL-4, whereas directly activated iNKT cells often produce both cytokines simultaneously (122). The weak TCR signaling that occurs during indirect iNKT cell activation promotes IFN- $\gamma$ production by inducing histone $\mathrm{H} 4$ acetylation near the IFN- $\gamma$ locus. This enables iNKT cells to produce IFN- $\gamma$ upon subsequent exposure to IL-12 and IL-18 without concurrent TCR stimulation (114). Unlike during direct activation, iNKT cells remain motile during stimulation with cytokines, which may enable them to disseminate IFN- $\gamma$ as they migrate, amplifying their impact on immune responses (114). It is likely that IAV vaccines trigger several indirect activation-mediated iNKT cell effector functions and that some of these responses will support (or perhaps counteract) the direct activation effects of co-delivered glycolipid antigens. In this scenario, achieving optimal IAV vaccine immunity will require studies to 
evaluate combining different dosages of iNKT cell agonists and IAV vaccines.

\section{HELPER FUNCTIONS OF INKT CELLS}

iNKT cells are capable of generating immune responses that in many ways mirror conventional $\mathrm{CD} 4^{+} \mathrm{T}$ cell help (Figure 1). Activated iNKT cells induce APCs to mature when they engage antigen-bound CD1d on their surface (123). These iNKT cellconditioned APCs, in turn, produce cytokines and $\mathrm{T}$ cell costimulatory molecules that further prime iNKT cells, causing them to upregulate $\mathrm{CD} 40 \mathrm{~L}$, and secrete IFN- $\gamma$ and granulocytemacrophage colony-stimulating factor. This induces surrounding APCs to mature and activate additional iNKT cells $(113,123$, 124). iNKT cell-licensed APCs prime conventional $\mathrm{CD} 4^{+} \mathrm{T}$ cells against co-delivered peptide antigens, which results in enhanced cytotoxic $\mathrm{CD}^{+} \mathrm{T}$ cell responses and induces $\mathrm{CD} 4^{+} \mathrm{T}$ cells to become follicular helper $\mathrm{T}\left(\mathrm{T}_{\mathrm{FH}}\right)$ cells. iNKT cell-conditioned APCs also acquire the ability to cross-present peptide antigens to $\mathrm{CD}^{+} \mathrm{T}$ cells $(125-127)$. The mechanisms through which iNKT cells enhance humoral immune responses have been extensively reviewed (128-132). One mode involves iNKT cells directly interacting with B cells presenting glycolipid ligands on CD1d, which is referred to as cognate B cell help. Initially, iNKT cells recognize glycolipid antigens on dendritic cells (DCs) and differentiate into iNKT follicular helper (iNKT $\left.\mathrm{FH}_{\mathrm{FH}}\right)$ cells that adopt a phenotype similar to $\mathrm{T}_{\mathrm{FH}}$ cells $(133,134)$. These iNKT $\mathrm{FH}$ cells then activate $\mathrm{B}$ cells specific for protein antigens through a process that requires CD1d expression by $\mathrm{B}$ cells, B7-1/B7-2, and CD40 ligation by the iNKT cells and the secretion of IFN- $\gamma$ and IL-21. Cognate B cell help stimulates plasmablast expansion, germinal center formation, antibody class switching, and moderate affinity maturation $(135,136)$. iNKT cells can also provide non-cognate B cell help which occurs when iNKT cells indirectly activate $\mathrm{B}$ cells by inducing $\mathrm{T}_{\mathrm{FH}}$ cells specific for protein antigens displayed by B cells (137). This mode of activation is thought to drive enhanced antibody production when $\alpha$-GalCer is co-administered with immunizing antigens; protein and $\alpha$-GalCer are internalized by DCs that simultaneously present peptide fragments of the protein antigen on MHC class II to naïve CD4+T cells and $\alpha$-GalCer on CD1d to iNKT cells. The $\mathrm{T}_{\mathrm{FH}}$ cells that result provide CD1dindependent antigen-specific help for the proliferation of $\mathrm{B}$ cells in germinal centers, antibody class switching, affinity maturation, and the generation of plasma cells and memory B cells. In addition, activated iNKT cells trans-activate NK cells to produce large quantities of IFN- $\gamma$ that stimulate B cells to secrete IgG (138). Non-cognate B cell help is probably important after virus exposure when iNKT cells may shape B cell responses by producing an early wave of IL-4 that seeds germinal centers and activates antigen-experienced B cells (139).

The benefit of eliciting $\mathrm{T}$ helper responses via iNKT cells compared to $\mathrm{CD} 4^{+} \mathrm{T}$ cells is that iNKT cells constitute a much greater fraction of total $\mathrm{T}$ cells than any antigen-specific $\mathrm{CD} 4^{+} \mathrm{T}$ cell clone $(140,141)$. Furthermore, iNKT cells can be globally and specifically activated using $\alpha$-GalCer analogs due to the highly non-polymorphic CD1d molecule $(67,78,142)$. Conversely, conventional $\mathrm{CD}^{+} \mathrm{T}$ cells are restricted by the high level of inter-individual MHC class II polymorphism, which limits the efficacy of peptide-based vaccines in outbred populations. Co-administering iNKT cell ligands with vaccines that induce a wide array of conventional $\mathrm{T}$ helper cell responses has the potential to induce wide-ranging cellular and humoral immune responses capable of greatly improving the durability and the cross-protection of vaccines, including against IAVs.

\section{ROLE OF INKT CELLS IN IMMUNITY TO IAV INFECTIONS}

Mice lacking iNKT cells are more susceptible to IAV infections than iNKT cell-intact mice (143-146), indicating that these cells contribute to IAV immunity. iNKT cell activation is likely through the indirect pathway as IAVs contain no known iNKT cell ligands. Nevertheless, stimulation may be enhanced by interactions with CD1d-bound endogenous glycolipids which often increase after viral infection (147). iNKT cells migrate to the lungs during the early stages of IAV infections, alongside the recruitment of neutrophils and the rapid induction of pro- and anti-inflammatory cytokines that prime immune cells, including iNKT cells $(146,148)$. Mouse studies have reported that airway-resident iNKT cells prevent virus replication and limit lung damage through a combination of (i) reducing the suppressive capacity of myeloid-derived suppressor cells that inhibit influenza-specific immune responses (143), (ii) activating lung-resident NK cells (145), and (iii) directly lysing IAV-infected monocytes (144). In addition, iNKT cells stimulated by IL- $1 \beta$ and IL-23 produce large amounts of IL-22 that protects the lung epithelium from influenza-mediated damage (149). iNKT cells have also been investigated for their role in shaping pre-existing immunity against re-infections with the same or heterologous influenza viruses. Benton et al. showed that CD1d knockout mice previously infected with A/Puerto Rico/8/34 (H1N1) or A/Philippines/2/82/X-79 (H3N2) and re-infected after 4 weeks with the correspondent homologous or heterologous H1N1 or $\mathrm{H} 3 \mathrm{~N} 2$ viruses were just as susceptible to re-infection as wildtype mice (150). These findings suggest that iNKT cell responses might be superfluous for generating immune memory or crossprotection after a natural IAV infection. This contrasts with other studies showing that therapeutically activated iNKT cells improve pre-existing immunity from IAV vaccination and suggests that immunity generated by iNKT cells might differ depending on whether they are activated indirectly during an IAV infection or via glycolipid antigens.

\section{STUDIES USING INKT CELL AGONISTS WITH IAV VACCINES}

At least 17 publications have reported the effects of iNKT cell agonists for adjuvanting IAV vaccines (Table 1). Most of these studies have used mice because they are relatively inexpensive and compatible with a wide variety of vaccine formats. However, swine and non-human primates [pigtail 


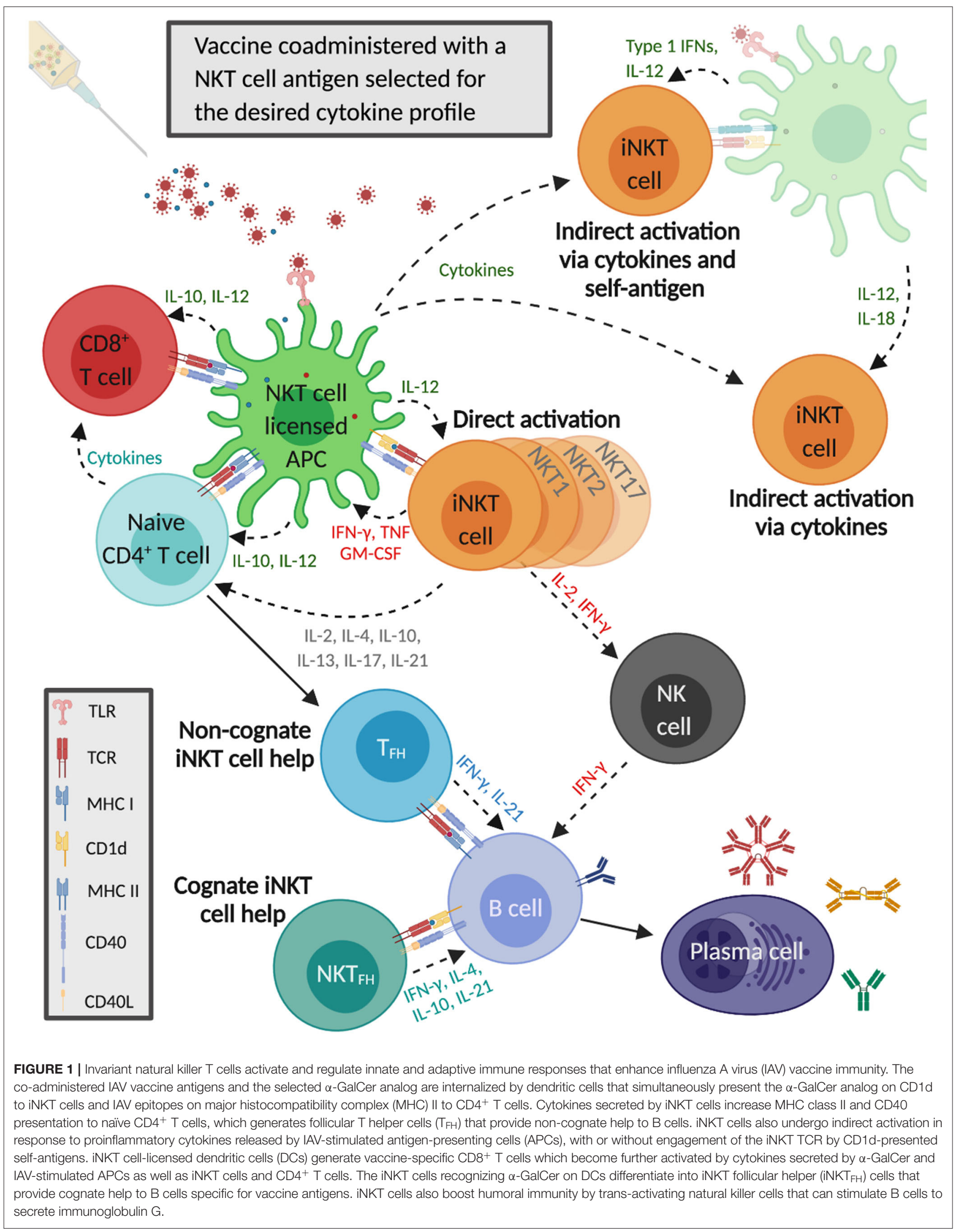


macaques (Macaca nemestrina)] have also been tested. To our knowledge, Ko et al. were the first group to explore adjuvanting IAV vaccines with iNKT cell agonists (26). They reported that $\mathrm{BALB} / \mathrm{c}$ mice intranasally co-administered with three doses (1 week apart) of $\alpha$-GalCer and $\mathrm{HA}$ antigen derived from the mouse-adapted A/PR/8/34 (PR8, H1N1) IAV were much better protected from a lethal dose of the homologous virus than mice immunized with vaccine alone. $\alpha$-GalCer induced greater levels of mucosal and systemic IgA and IgG antibodies. The same group later demonstrated that a single intranasal vaccination with inactivated PR 8 and $\alpha$-GalCer was sufficient to induce longlasting PR8-specific IgG and IgA that protected mice from PR8 infection 3 months after the vaccination (22).

iNKT cell agonists have also been assessed for their ability to improve vaccine-mediated cross-protection against heterologous and heterosubtypic virus infections. Kamijuku et al. administered $\alpha$-GalCer to BALB/c mice in combination with HA-based vaccines derived from a variety of IAV strains. Strong protection was induced against heterologous IAV strains within the same HA vaccine subtype and partial protection was generated against the heterosubtypic strains (23). A follow-up study demonstrated that an inactivated whole-virion vaccine of H5N1 IAV generated robust cross-protection against a heterologous H5N1 IAV strain when administered intranasally with, but not without, $\alpha$-GalCer. The cross-protective effects of iNKT cell activation were found to be mediated by mucosal IgA production and effector responses that require IL-4, but not IFN- $\gamma$ (23).

Other strategies that have been tested include a study where the $\alpha$-GalCer derivative $\alpha$-C-galactosylceramide ( $\alpha$-C-GalCer) enhanced the immune response elicited by a live attenuated $\mathrm{A} / \mathrm{PR} / 8 / 34$ virus expressing only the first 73 amino acids in the NS1 gene; NS1 is needed to inhibit critical innate host immune factors (27). BALB/c mice were co-administered the live attenuated virus (LAV) vaccine with different doses of $\alpha$ $\mathrm{C}$-GalCer ranging from 0 to $4 \mu \mathrm{g} /$ mouse. Interestingly, only mice that received low doses of $\alpha-C$-GalCer survived, while mice treated with the $4 \mu \mathrm{g}$ dose or the LAV vaccine alone were not protected. This finding suggests that activating iNKT cells too strongly may be detrimental for LAV vaccine applications since their limited replication capacity might be abolished by iNKT cell-mediated innate immune responses before they have had an opportunity to induce vaccine-specific immunity. $\alpha$ GalCer has also been used to adjuvant the normally poorly immunogenic IAV M2 ectodomain (M2e); BALB/c mice coimmunized with $\mathrm{M} 2 \mathrm{e}$ and $\alpha$-GalCer were fully protected against a highly pathogenic $\mathrm{H} 5 \mathrm{~N} 1$ avian IAV infection and exhibited significantly reduced morbidity and lung viral titers compared to mice that were immunized without $\alpha$-GalCer (25). The enhanced protection was associated with augmented IgG1 and IgG2 antibody levels and greater IFN- $\gamma$ and IL-4 upregulation after infection. Another study tested the efficacy of $\alpha$-GalCerpeptide conjugated vaccines composed of synthetic long peptides (SLP) containing an immunogenic peptide covalently attached to $\alpha$-GalCer by a cleavable linker (28). This ensures that the vaccine peptide and $\alpha$-GalCer are delivered to the same APC and enables iNKT cells to license the same APCs involved in stimulating conventional $\mathrm{CD}^{+}$and $\mathrm{CD}^{+} \mathrm{T}$ cell responses against the vaccine antigen. C57BL/6 mice were vaccinated with $\alpha$-GalCer conjugated SLPs composed of an immunogenic peptide of chicken ovalbumin and challenged 6 weeks later with a recombinant ovalbumin expressing IAV. The SLP vaccine provided much greater protection than previous infection with the backbone virus. However, it remains to be determined whether this approach provides protection against non-OVAexpressing IAVs. Another strategy used an "adjuvant vector cell" (aAVC) system comprised of $\mathrm{CD}^{+} \mathrm{d}^{+} \mathrm{HA}$ mRNA-transfected cell lines (NIH3T3 for mice and HEK293 cells for humans) loaded with $\alpha$-GalCer. C57BL6/J mice immunized with aAVCHA were protected from a lethal dose of PR8 2 weeks later. The efficacy of this approach seemed to depend on the formation of germinal centers and $\mathrm{T}_{\mathrm{FH}}$ cells and was more effective than a co-administration of free antigen and $\alpha$-GalCer (29).

Many articles reporting the adjuvant activities of iNKT cells for IAV vaccines have used the intranasal delivery route of administering $\alpha$-GalCer because of the importance of this site for pulmonary immunity. $\alpha$-GalCer administered by this route remains localized to the nasal-associated lymphoid tissues and cervical lymph nodes where it becomes concentrated in the intracellular vesicles of DCs. These DCs co-localize with iNKT cells that accumulate in these tissues through a process that requires the chemokine receptor CXCR6 and its ligand CXCL16 (23). $\alpha$-GalCer can also induce effective immunity when delivered to tissues beyond the site of infection. For instance, Galli et al. showed that mice immunized via the intramuscular route with $\alpha$-GalCer admixed with HA/NA subunits from human influenza viruses generated antibody titers that were 1-2 logs higher than mice immunized with protein alone and greatly enhanced survival after a lethal IAV infection (30).

iNKT cell responses have also shown promise for generating cross-reactive $\mathrm{CD}^{+} \mathrm{T}$ cells against serologically distinct IAV subtypes, which is a major shortcoming of current IAV vaccines. Guillonneau et al. examined cytotoxic $\mathrm{CD}^{+} \mathrm{T}$ cell responses in C57BL/6 mice subcutaneously immunized with an inactivated PR8 vaccine, with and without $\alpha$-GalCer, that were infected with a heterosubtypic H3N2 IAV 6 weeks later (24). iNKT cell activation enhanced the survival of long-lived memory cytotoxic $\mathrm{CD}^{+} \mathrm{T}$ cells capable of clearing virus from the lungs while paradoxically diminishing acute phase cytotoxic $\mathrm{T}$ cell responses through iNKT cell-dependent production of indoleamine 2,3dioxygenase, an immune suppressive enzyme (24). The induction of long-lasting $\mathrm{CD}^{+} \mathrm{T}$ cells was associated with the upregulation of $\mathrm{Bcl}$-2, which is a pro-survival gene. The adjuvant effects of iNKT cells have also shown potential to improve DNA-based vaccines, which stimulate only modest immunity in humans. Two studies have demonstrated that vaccinating mice with $\alpha$ GalCer derivatives and DNA vaccines encoding an HA consensus sequence of an H5N1 IAV or the IAV M2 protein induces M2specific cellular and humoral immune responses and protection from virus challenge $(21,31)$.

Although mouse models have demonstrated that iNKT cell activities can greatly enhance IAV vaccines, it remains unclear whether the same approach would be successful in humans as mice are not natural IAV hosts and mouse and human iNKT cells differ considerably in frequency, subsets, and tissue 
TABLE 1 | Summary of studies on modulating immune responses to influenza A virus (IAV) using invariant natural killer T (iNKT) cell agonists.

\begin{tabular}{|c|c|c|c|c|c|c|}
\hline \multirow[t]{2}{*}{ Animal model } & \multicolumn{2}{|r|}{ Vaccination } & \multirow[t]{2}{*}{ Vaccine format } & \multirow{2}{*}{$\begin{array}{l}\text { iNKT cell agonist } \\
\text { (dose per animal) }\end{array}$} & \multirow[t]{2}{*}{ Mode of action } & \multirow[t]{2}{*}{ References } \\
\hline & Route & Strain/subunit & & & & \\
\hline Mouse (BALB/C) & i.n. & H1N1 PR8 & $\begin{array}{l}\text { Immunization with PR8 HA antigen with } \\
\alpha \text {-GalCer three times at } 1 \text {-week intervals. } \\
\text { Infection with } 20 \text { LD }_{50} \text { PR8 } 2 \text { weeks after } \\
\text { final immunization. }\end{array}$ & $\begin{array}{l}\alpha-\text { GalCer }(0.125 \\
0.5,2 \mu \mathrm{g})\end{array}$ & $\begin{array}{l}\alpha \text {-GalCer induced mucosal secretory } \\
\text { IgA as well as systemic IgG antibody } \\
\text { responses against virus-derived } \\
\text { antigen and reduced clinical signs. }\end{array}$ & (26) \\
\hline Mouse (BALB/c) & i.n. & H1N1 PR8 & $\begin{array}{l}\text { Immunization with inactivated PR8 with } \\
\alpha \text {-GalCer. Infection with } 20 \text { LD50 PR8 } 2 \\
\text { weeks and } 3 \text { months after immunization. }\end{array}$ & $\alpha-$ GalCer $(0.5 \mu \mathrm{g})$ & $\begin{array}{l}\alpha \text {-GalCer induced both mucosal and } \\
\text { systemic antibody responses, } \\
\text { provided protective immunity against } \\
\text { challenge with live PR8 and induced } \\
\text { cytotoxic CD8 }{ }^{+} \text {T cells. }\end{array}$ & $(22)$ \\
\hline Mouse (BALB/c) & \multicolumn{2}{|c|}{$\begin{aligned} & \text { i.n./i.m. } \text { H1N1 PR8 } \\
& \text { H1N1A/Yamagata } \\
& \text { H3N2A/Guizhou } \\
& \text { B/lbaraki }\end{aligned}$} & $\begin{array}{l}\text { Immunization with PR8, AYamagata, } \\
\text { A/Guizhou, or B/lbaraki HA vaccine with } \\
\alpha \text {-GalCer twice at } 4 \text { weeks apart. Infection } \\
\text { with } 40 \text { LD }_{50} \text { PR8 } 2 \text { weeks after the } \\
\text { second immunization. }\end{array}$ & $\alpha$-GalCer $(2 \mu g)$ & $\begin{array}{l}\text { i.n., not i.m., vaccination (PR8 and } \\
\text { AYamagata) with } \alpha \text {-GalCer boosted } \\
\text { IgA and lgG and cross-protection } \\
\text { against heterosubtypic virus infection. }\end{array}$ & (23) \\
\hline Mouse (BALB/c) & i.n. & H1N1 PR8 & $\begin{array}{l}\text { Immunization with PR8 with } \alpha \text {-GalCer } \\
\text { twice at } 4 \text { weeks apart. Infection with } 40 \\
\text { LD }_{50} \text { AYamagata, A/Guizhou, or B/lbaraki } \\
2 \text { weeks after the second immunization. }\end{array}$ & $\alpha$-GalCer $(2 \mu \mathrm{g})$ & $\begin{array}{l}\text { i.n. vaccination with } \alpha \text {-GalCer } \\
\text { protected against challenge with } \\
\text { homologous (A/PR8) and } \\
\text { heterologous (A/Yamagata) viruses. }\end{array}$ & (23) \\
\hline Mouse (BALB/c) & i.n. & H5N1 NIBRG14 & $\begin{array}{l}\text { Immunization with NIBRG14 (H5N1) } \\
\text { inactivated vaccine with } \alpha \text {-GalCer twice, } 4 \\
\text { weeks apart. Infection with } 10^{3} \text { PFU of } \\
\text { AVietnam (H5N1) or A/HK483 (H5N1) } \\
\text { influenza virus } 2 \text { weeks after the second } \\
\text { immunization. }\end{array}$ & $\alpha$-GalCer $(2 \mu \mathrm{g})$ & $\begin{array}{l}\text { i.n. vaccination with } \alpha-\mathrm{GalCer} \\
\text { increased nasal lgA and serum IgG } \\
\text { and induced cross-protection against } \\
\text { H5N1 influenza infection. }\end{array}$ & (23) \\
\hline Mouse (BALB/c) & i.n. & H1N1 rNS1 1-73 & $\begin{array}{l}\text { Immunization with live attenuated rNS1 } \\
\text { 1-73 with different amounts of } \alpha \text {-C-GalCer. } \\
\text { Infection with } 100 \text { LD }_{50} \text { PR8 } 3 \text { weeks after } \\
\text { the immunization. }\end{array}$ & $\begin{array}{l}\alpha-C-G a l C e r(0.11 \\
0.33,1,2,3,4 \mu \mathrm{g})\end{array}$ & $\begin{array}{l}\alpha-C-G a l C e r \text { used between } 0.1 \text { and } 1 \\
\mu g \text { per mouse reduced mortality and } \\
\text { morbidity. The adjuvant also } \\
\text { increased the amount of influenza } \\
\text { virus-specific total IgG, IgG1, and } \\
\text { IgG2a antibodies as well as IFN- } \gamma \\
\text { secreting CD8 }{ }^{+} \text {T cells. }\end{array}$ & $(27)$ \\
\hline Mouse (BALB/c) & i.n. & H1N1 PR8 & $\begin{array}{l}\text { Immunization with inactivated PR8 with } \\
\alpha \text {-GalCer or } \alpha \text {-GalCer analogs. Infection } \\
\text { with } 5 \text { LD } 50 \text { PR8 } 4 \text { weeks after the } \\
\text { immunization or } 100 \text { LD }_{50} \text { PR8 } 5 \text { weeks } \\
\text { after immunization. }\end{array}$ & $\begin{array}{l}\alpha \text {-GalCer }(0.5 \mu \mathrm{g}) \\
\text { KBC-007 }(0.5 \mu \mathrm{g}) \\
\text { KBC-009 }(0.5 \mu \mathrm{g})\end{array}$ & $\begin{array}{l}\text { Co-immunization with } \alpha \text {-GalCer, } \\
\text { KBC-007 and KBC-009 increased } \\
\text { PR8-specific systemic lgG and } \\
\text { mucosal IgA. } \alpha \text {-GalCer and KBC-009 } \\
\text { (but not KBC-007) increased } \\
\text { antigen-specific lymphocyte } \\
\text { proliferation, cytokine production, and } \\
\text { cytotoxic CD8 }{ }^{+} \text {T cell activity and } \\
\text { induced complete protection from live } \\
\text { virus infection. }\end{array}$ & (32) \\
\hline Mouse (C57BL/6) & i.v. & $\begin{array}{l}\text { H1N1 } \\
\text { PR8-OVA257 }\end{array}$ & $\begin{array}{l}\text { Immunization with SLP-conjugated } \\
\text { vaccine PR8-OVA257 with } \alpha \text {-GalCer. } \\
\text { Infection with } 10^{4} \text { PFU HKx31-OVA257 } \\
6 \text {-8 weeks after the immunization. }\end{array}$ & $\alpha$-GalCer (76 ng) & $\begin{array}{l}\alpha \text {-GalCer-peptide conjugates induced } \\
\text { OVA-specific T cell responses and } \\
\text { protected against IAV infection. }\end{array}$ & (28) \\
\hline Mice (C57BL/6) & i.m. & $\begin{array}{l}\text { HA/NA from } \\
\text { H3N2 PNM07 }\end{array}$ & $\begin{array}{l}\text { Immunization with PNM07 protein and } \\
\alpha \text {-GalCer twice at } 2 \text { weeks apart. }\end{array}$ & $\alpha$-GalCer $(0.1 \mu \mathrm{g})$ & $\begin{array}{l}\text { Immunization with H3N2 PNM07 plus } \\
\alpha \text {-GalCer increased titers of } \\
\text { H3N2-specific antibodies. }\end{array}$ & (30) \\
\hline Mouse (C57Bᄂ/6) & i.m. & $\begin{array}{l}\text { HANA from } \\
\text { H1N1 NC20 }\end{array}$ & $\begin{array}{l}\text { Immunization with NC20 protein with } \\
\alpha \text {-GalCer twice at } 2 \text { weeks apart. Infection } \\
\text { with } 100 \text { LD }_{50} \mathrm{H} 1 \mathrm{~N} 1 \mathrm{~A} W \mathrm{~S} / 332 \text { weeks } \\
\text { after the second immunization. }\end{array}$ & $\alpha-$ GalCer $(0.1 \mu \mathrm{g})$ & $\begin{array}{l}\alpha \text {-GalCer increased the survival rate } \\
\text { after challenge. }\end{array}$ & (30) \\
\hline Mouse (C57BL/6) & i.m. & H3N2 PNM07 & $\begin{array}{l}\text { Immunization with } \mathrm{H} 3 \mathrm{~N} 2 \text { PNM07 protein } \\
\text { with } \alpha \text {-GalCer twice at } 0 \text { and } 2 \text { weeks, } \\
\text { boosted with PNM07 at } 30 \text { weeks. }\end{array}$ & $\alpha$-GalCer $(0.1 \mu \mathrm{g})$ & $\begin{array}{l}\text { Immunization with H3N2 PNM07 plus } \\
\alpha \text {-GalCer resulted in a higher antibody } \\
\text { response and increased expansion of } \\
\text { the antigen-specific memory B cells. }\end{array}$ & (30) \\
\hline Mouse (C57BL/6) & s.c. & H1N1 PR8 & $\begin{array}{l}\text { Immunization with inactivated PR8 with } \\
\alpha \text {-GalCer. Infection with } 10^{4} \text { PFU of live } \\
\text { H3N2 HKx31 } 6 \text { weeks after immunization. }\end{array}$ & $\alpha$-GalCer $(1 \mu \mathrm{g})$ & $\begin{array}{l}\text { Vaccination with } \alpha \text {-GalCer increased } \\
\text { the survival of long-lived memory } \\
\text { cytotoxic CD8 }{ }^{+} \mathrm{T} \text { cell populations } \\
\text { capable of boosting protection } \\
\text { against heterologous IAV challenge. }\end{array}$ & (24) \\
\hline
\end{tabular}


TABLE 1 | Continued

\begin{tabular}{|c|c|c|c|c|c|c|}
\hline \multirow[t]{2}{*}{ Animal model } & \multicolumn{2}{|c|}{ Vaccination } & \multirow[t]{2}{*}{ Vaccine format } & \multirow{2}{*}{$\begin{array}{l}\text { iNKT cell agonist } \\
\text { (dose per animal) }\end{array}$} & \multirow[t]{2}{*}{ Mode of action } & \multirow[t]{2}{*}{ References } \\
\hline & Route & Strain/subunit & & & & \\
\hline Mouse (BALB/c) & i.m. & $\begin{array}{l}\text { pCHA5 for } \\
\text { H5N1 }\end{array}$ & $\begin{array}{l}\text { Immunization with pCHA5 with C34 twice } \\
\text { at } 3 \text { weeks apart. Infection with } 200 \text { LD } 50 \\
\text { NIBRG14 (a reassortant H5N1 virus) } 2 \\
\text { weeks after the immunization. }\end{array}$ & C34 $(2 \mu \mathrm{g})$ & $\begin{array}{l}\text { C34 increased titers of HA-specific } \\
\text { antibodies and T cells and improved } \\
\text { survival after challenge. }\end{array}$ & (31) \\
\hline Mouse (C57BL/6) & i.v. & H1N1 PR8 & $\begin{array}{l}\text { Immunization with PR8 HA } \\
\text { mRNA-transfected CD1d-allogeneic cells } \\
\text { loaded with } \alpha \text {-GalCer (aAVC-HA). Infection } \\
\text { with } 10^{3} \text { PFU PR8 } 2 \text { weeks after the } \\
\text { immunization. }\end{array}$ & $\begin{array}{l}5 \times 10^{5} \text { aAVC-HA } \\
\text { precultured with } \\
\alpha \text {-GalCer } \\
(500 \mathrm{ng} / \mathrm{mL})\end{array}$ & $\begin{array}{l}\text { Vaccination with aAVC-HA preserved } \\
\text { body weight, increased survival after } \\
\text { infection, and increased titers of } \\
\text { HA-specific IgG. }\end{array}$ & (29) \\
\hline Mouse (BALB/c) & i.p. & M2e peptide & $\begin{array}{l}\text { Immunization with M2e peptide with } \\
\alpha \text {-GalCer twice at } 3 \text { weeks apart. Infection } \\
\text { with } 10^{3} \text { PFU H5N1 } 3 \text { weeks after the final } \\
\text { immunization. }\end{array}$ & $\alpha$-GalCer $(1 \mu \mathrm{g})$ & $\begin{array}{l}\alpha \text {-GalCer co-administered with } \mathrm{M} 2 \mathrm{e} \\
\text { peptide reduced morbidity, mortality } \\
\text { and up-regulated IFN- } \gamma, \text { IL-4 after } \\
\text { challenge. }\end{array}$ & (25) \\
\hline Mouse (BALB/C) & i.m. & $\begin{array}{l}\text { DNA vaccine } \\
\text { encoding M2 }\end{array}$ & $\begin{array}{l}\text { Immunization with DNA vaccine encoding } \\
\text { M2 with } \alpha \text {-GalCer three times at 2-week } \\
\text { intervals. Infection with } 1 \text { LD }_{90} \text { PR8 } 2 \\
\text { weeks after the final immunization. }\end{array}$ & $\alpha$-GalCer $(1 \mu \mathrm{g})$ & $\begin{array}{l}\alpha \text {-GalCer increased M2-specific IgG; } \\
\text { lymphocyte proliferation; IFN- } \gamma \text { and } \\
\text { IL-12 and IL-4 production; and } \\
\text { survival rate after virus challenge. }\end{array}$ & (21) \\
\hline Mouse (BALB/C) & i.m. & $\begin{array}{l}\text { H1N1 CA07, } \\
\text { A/Hong Kong } \\
\text { (H3N2), } \\
\text { B/Phuket, and } \\
\text { B/Texas }\end{array}$ & $\begin{array}{l}\text { Immunization with split influenza HA } \\
\text { vaccine with 7DW8-5 twice at 2-week } \\
\text { intervals. Infection with } 10 \mathrm{MLD}_{50} \mathrm{H} 1 \mathrm{~N} 1 \\
\text { CA04 } 3 \text { weeks after the final immunization. }\end{array}$ & $\begin{array}{l}\text { 7DW8-5 (1 } \mu \mathrm{g} \text { or } 10 \\
\mu \mathrm{g})\end{array}$ & $\begin{array}{l}\text { 7DW8-5 was sufficient to protect the } \\
\text { mice from lethal infection but did not } \\
\text { completely prevent virus replication. }\end{array}$ & (33) \\
\hline Pig & i.n. & $\mathrm{H} 1 \mathrm{~N} 1 \mathrm{OH} 07$ & $\begin{array}{l}\text { Immunization with inactivated SwIV OHO7 } \\
\text { with } \alpha \text {-GalCer once. Infection with } \\
\text { homologous SwIV OHO7 }\left(10^{6} \mathrm{TCID}_{50} \text { per }\right. \\
\text { pig) } 3 \text { weeks after the immunization. }\end{array}$ & $\begin{array}{l}\alpha-\text { GalCer }(50 \text { or } 250 \\
\mu \mathrm{g})\end{array}$ & $\begin{array}{l}\alpha \text {-GalCer increased IAV-specific } \\
\text { mucosal IgA and upregulated the } \\
\text { expression of BAFF. }\end{array}$ & (151) \\
\hline Pig & i.n. & $\mathrm{H} 1 \mathrm{~N} 1 \mathrm{OHO7}$ & $\begin{array}{l}\text { Immunization with inactivated SwIV OHO7 } \\
\text { with } \alpha \text {-GalCer once. Infection with } \\
\text { homologous SwIV OHO7 }\left(10^{6} \mathrm{TCID}_{50} \text { per }\right. \\
\text { pig) } 3 \text { weeks after the immunization. }\end{array}$ & $\begin{array}{l}\alpha \text {-GalCer (50 or } 250 \\
\mu \mathrm{g})\end{array}$ & $\begin{array}{l}\alpha \text {-GalCer }(250 \mu \mathrm{g}) \text { administration } \\
\text { reduced pulmonary viral load and } \\
\text { increased SwIV-specific IgA secretion } \\
\text { both in the lungs and the airways. }\end{array}$ & (152) \\
\hline Pig & i.m. & H1N1 CA04 & $\begin{array}{l}\text { Immunization with inactivated } \mathrm{H} 1 \mathrm{~N} 1 \mathrm{CAO} 4 \\
\text { with } \alpha \text {-GalCer twice at } 16 \text {-day intervals. } \\
\text { Infection with } 10^{6} \mathrm{TCID}_{50} \mathrm{CA04} 16 \text { days } \\
\text { after the immunization. }\end{array}$ & $\begin{array}{l}\alpha-\text { GalCer }(100 \\
\mu \mathrm{g} / \mathrm{kg})\end{array}$ & $\begin{array}{l}\text { Vaccination with } \alpha \text {-GalCer enhanced } \\
\text { both systemic and mucosal } \\
\text { influenza-specific antibodies and } \\
\text { inhibited viral replication in the upper } \\
\text { and the lower respiratory tracts. }\end{array}$ & (153) \\
\hline Pigtail macaques & i.v. & $\begin{array}{l}\text { Live-attenuated } \\
\text { IAV encoding } \\
\text { three distinct } \\
\text { SIV epitopes } \\
\text { (flu-SIV) }\end{array}$ & $\begin{array}{l}\text { A single dose of } \alpha \text {-GalCer pulsed onto } \\
\text { whole blood for } 2 \mathrm{~h} \text { and re-infused with } \\
\text { flu-SIV; additional vaccinations without } \\
\alpha \text {-GalCer on days } 28,56 \text {, and } 119 \text {. }\end{array}$ & $\alpha$-GalCer $(5 \mu \mathrm{g})$ & $\begin{array}{l}\alpha-\text { GalCer reduced vaccine-specific } \\
\mathrm{CD} 8^{+} \mathrm{T} \text { cells and had no effect on the } \\
\text { frequency of iNKT cells or IAV-specific } \\
\text { antibodies; reduced influenza-specific } \\
\mathrm{CD} 8^{+} \mathrm{T} \text { cells. }\end{array}$ & (72) \\
\hline
\end{tabular}

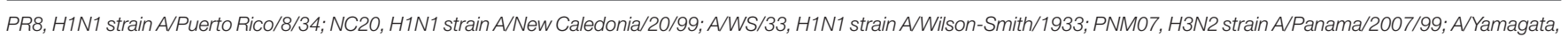

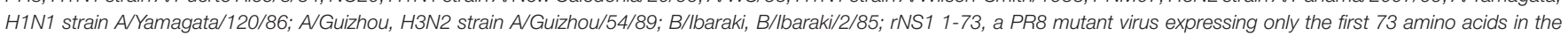

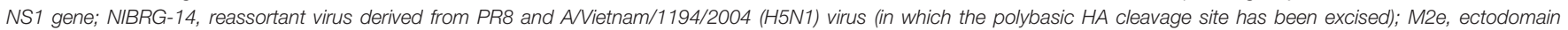

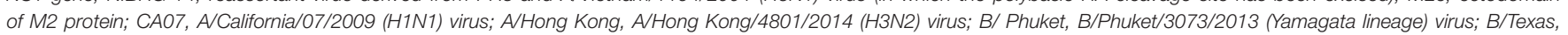

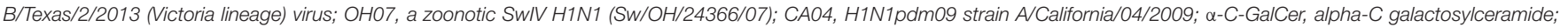

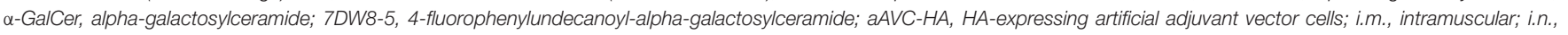
intranasal; i.p., intraperitoneal; s.c., subcutaneous; i.v., intravenous; WB, whole blood.

distribution. Therapeutically activating iNKT cells failed to improve anti-IAV cellular and humoral immune responses when attempted in pigtail macaques, which are considered a good translational model for human IAV infections (72). Nevertheless, we previously reported that $\alpha$-GalCer substantially increased the efficacy of a killed pandemic 2009 H1N1 IAV vaccine in pigs that were challenged with the homologous virus. Protection was associated with higher levels of vaccine-specific antibodies and $\mathrm{T}$ cells and reduced viral replication in the upper and lower respiratory tract compared to pigs that received the vaccine alone
(153). Similar results were obtained in studies by Dwivedi et al. and Renu et al., who showed that intranasal co-administration of $\alpha$-GalCer with UV-inactivated $\mathrm{H} 1 \mathrm{~N} 1$ vaccines increased mucosal IgA levels, upregulated lung expression of the B cell activation factor BAFF, and substantially reduced virus loads in pigs (151, 152). Collectively, these results are encouraging as swine and human iNKT cells share several key characteristics, and like humans, pigs are natural hosts of IAVs. Furthermore, there may also be potential to use iNKT cell antigens for vaccines against swine influenza and other pig pathogens. 


\section{FACTORS THAT INFLUENCE THE ADJUVANT POTENTIAL OF INKT CELLS}

Studies in mice have established that the effects of iNKT cell activation are influenced by a variety of interacting parameters, which should be considered when attempting to use these agents to adjuvant vaccines. Some of the main factors are discussed below.

\section{iNKT Cell Subsets}

The iNKT cell compartment consists of multiple subsets that play distinct roles during pathogen-host interactions and which produce different effector functions after glycolipid stimulation. Subset development occurs through a linear differentiation process characterized by sequential changes in surface markers and transcription factors. Human iNKT cells develop into CD4 ${ }^{-}$ or $\mathrm{CD}_{4}^{+}$subsets that secrete Th1 or a mixture of Th1 and Th2 cytokines upon activation, respectively $(54,154)$. However, these differences in cytokine production are less apparent for mouse iNKT cells (85). Another difference is that the $\mathrm{CD} 4^{+}$subset of iNKT cells predominates in mice (155), while human iNKT cells are mostly $\mathrm{CD}^{-}(54,156,157)$. Like humans, iNKT cells in pigs are mainly $\mathrm{CD}^{-}(52,68,75,153)$, and both humans and pigs contain a subset of $\mathrm{CD} 8^{+}{ }$iNKT cells which is absent in mice $(54,68,75,156,157)$.

Mouse iNKT cell subsets can be classified according to their development lineages that are acquired during thymic selection (Table 2). These are composed of the three major functionally distinct subsets, NKT1, NKT2, and NKT17, which express the master transcription factors T-bet, GATA-3, and ROR $\gamma$ t that also, respectively, engender the fate of Th1, Th2, and Th17 T helper cell subsets as well as ILC1, ILC2, and ILC3 innate lymphoid cells (95, 158-161, 163-165). Each iNKT subset expresses different levels of the transcription factor PLZF, which is critical for the development and the innate functions of iNKT cells (168-170). Additional iNKT cell subsets that differentiate extrathymically have been identified, including $\mathrm{NKT}_{\mathrm{FH}}$ and NKT10 cells. $\mathrm{NKT}_{\mathrm{FH}}$ cells are characterized by the expression of $\mathrm{Bcl}-6$ and the secretion of IL-21 and are located in the germinal centers of lymphoid organs. $\mathrm{NKT}_{\mathrm{FH}}$ cells provide help to $\mathrm{B}$ cells during the formation of germinal centers and drive the affinity maturation of antibodies toward lipid antigens $(134,135)$. NKT10 cells are equivalent to type- 1 regulatory $\mathrm{T}$ cells ( $\mathrm{T}_{\mathrm{REGS}}$ ) and produce IL-10 and IL-2. This subset induces the differentiation of antiinflammatory macrophages and provides help to $\mathrm{T}_{\text {REGS. Instead }}$ of expressing PLZF like other NKT cells, NKT10 express E4BP4, a transcription factor associated with IL-10 production (166).

Individual iNKT cell subsets differentially accumulate in lymphoid and non-lymphoid tissues (171). In mice, most liver iNKT cells are NKT1 cells, while NKT2 cells predominate in the lung, spleen, and mesenteric lymph nodes (56, 162, 171). NKT17 cells are most plentiful in the lymph nodes, lung, and skin $(56,162,171)$, while NKT10 cells preferentially accumulate in adipose tissue $(167,171)$ and $\mathrm{NKT}_{\mathrm{FH}}$ cells localize in germinal centers, especially in the spleen $(134,135)$. The effector functions of each subset are distinct and range from NKT1 cells that stimulate proinflammatory responses capable of suppressing cancer and infectious agents $(83,172)$ to tolerogenic NKT2 and NKT10 cells that inhibit autoimmune diseases (173-175). Such diversity in function needs to be considered when targeting the adjuvant activities of iNKT cell agonists because, depending on the route of vaccinations, some subsets may have more influence on shaping anti-IAV immune responses than others, which could considerably affect the quality and the durability of protection. Another consideration is the extensive variability in iNKT cell subset ratios among inbred mouse strains and genetically outbred humans and animals, which can result in extensive variability in outcomes. Indeed different ratios of NKT1/NKT2 subsets are thought to underlie the dimorphic responses that $\alpha$-GalCer treatment elicits in $\mathrm{C} 57 \mathrm{BL} / 6$ and $\mathrm{BALB} / \mathrm{c}$ mice for a host of different diseases (95). Currently, a unifying model linking iNKT cell transcription factors and functions is lacking for humans (and other species). Nevertheless, iNKT cells are probably comprised of functionally distinct subsets in all species that expresses these cells. Accordingly, the variability in iNKT cell subsets should be considered a potential source of variation in people or animals administered glycolipids to stimulate iNKT cell adjuvant activities.

\section{iNKT Cell Agonists}

Since $\alpha$-GalCer is the first iNKT cell ligand to be discovered and strongly activates iNKT cells, this agent and its synthetic derivative KRN7000 have been widely used to study the therapeutic potential of iNKT cells, including their adjuvant activities $(18,19,176)$. $\alpha$-GalCer is a glycosylceramide molecule, composed of an $\alpha$-anomeric sugar linked to a 26-carbonlong fatty acid chain and an 18-carbon-long sphingosine base (15). While this glycolipid induces a mixed Th1/Th2 cytokine response, various structural analogs of $\alpha$-GalCer that skew iNKT cell cytokine production toward a Th1 or Th2 response have been developed. These modifications include altering the length, saturation level, and branching of the alkyl and sphingosine chains, while other derivatives contain modifications at the glycosyl head (96, 97, 173, 177-181).

In general, $\alpha$-GalCer analogs with truncated fatty acid chains or the addition of double bonds in the acyl chain, such as OCH $((2 \mathrm{~S}, 3 \mathrm{~S}, 4 \mathrm{R})-1-\mathrm{O}-(\alpha$-D-galactopyranosyl)-N-tetracosanoyl2-amino-1,3,4-non-anetriol) and C20:2, skew iNKT cells toward producing Th2 cytokines $(173,177)$. In contrast, iNKT cells can be preferentially activated to produce Th1-like cytokines by (i) $\alpha$-GalCer derivatives that contain a $\mathrm{CH} 2$ group in place of the glycosidic oxygen (180), (ii) $\alpha$-C-GalCer analogs that contain an oxygen residue in the galactose sugar ring (182), and (iii) 7DW85 and C34 analogs that, respectively, possess methylene and aromatic residues inserted into their fatty acid chains $(183,184)$. Most studies on the adjuvant activities of iNKT cells use $\alpha$ GalCer, which generates potent cellular and humoral immunity due to the mixed Th1/Th2 cytokines elicited. However, several Th1-inducing reagents, including 7DW8-5 and C-glycoside, substantially enhance vaccine responses against malaria, HIV, and IAV vaccines in mice $(33,180,183)$. Some studies have reported that these agents are superior to $\alpha$-GalCer for boosting vaccine-mediated immune responses due to a greater ability to 
TABLE 2 | Key characteristics of the main invariant natural killer T (iNKT) cell subsets.

\begin{tabular}{|c|c|c|c|c|}
\hline iNKT cell subset & Transcription factor & Signature cytokines & Tissue distribution & References \\
\hline NKT1 & T-bet, PLZFlow & IL-4, IFN- $\gamma$ & Liver, spleen, lung, small intestine & $(56,95,158-162)$ \\
\hline NKT2 & GATA3, PLZFi & IL-4, IL-5, IL-13 & Lung, spleen, mesenteric lymph nodes & $(56,159-163)$ \\
\hline NKT17 & ROR $\gamma t$, PL ZFint & $\mathrm{IL}-17, \mathrm{IL}-22$ & Lymph nodes, lung, skin & $(56,159-162,164,165)$ \\
\hline$N K T_{F H}$ & $\mathrm{Bcl}-6$ & $\| \mathrm{L}-21$ & Germinal centers of lymphoid organs & $(134,135)$ \\
\hline NKT10 & E4BP4, PLZF- & IL-10, IL-2 & Adipose tissue & $(166,167)$ \\
\hline
\end{tabular}

trans-activate other immune cells, especially NK cells, to produce IFN- $\gamma(92,183)$.

The burgeoning list of synthetic iNKT cell ligands provides new opportunities to tune iNKT cell responses for a desired vaccine-supporting immune outcome. For IAV vaccines, the most promising iNKT cell-stimulating antigens are those which polarize mouse iNKT cells to produce Th1 cytokines or a mixture of Th1 and Th2 cytokines, which are naturally important for antiviral immune responses. Nevertheless, many of these reagents do not polarize human iNKT cells to the same degree as mouse iNKT cells due partially to the structural differences in mouse and human CD1d molecules that affect TCR/CD1d/antigen interactions $(91,92,178)$. This is an important consideration for translating preclinical animal vaccine studies to humans.

\section{Vaccine Format}

Studies with different disease models have shown that $\alpha$ GalCer treatment can have diverse immune effects depending on the timing, route, and dose of $\alpha$-GalCer administration. Understanding how these parameters affect the adjuvant activities of therapeutically activated iNKT cells is critical for optimizing iNKT cell-adjuvanted IAV vaccines. The timing of $\alpha$-GalCer treatment is a concern for prime-boost vaccination strategies that administer more than one $\alpha-G a l C e r$ dose. This is because the strong activation from a primary vaccination may render iNKT cells hypo-responsive to an additional stimulation. Most studies on the adjuvant activities of iNKT cell agonists for IAV vaccines employ multiple vaccine applications (Table 1) even though iNKT cells are reported to remain anergic to restimulation within 3 months after the initial stimulation. These reports seldom assess whether increases in immune responses are from the effects of iNKT cells stimulation or from the vaccine antigen alone. However, it has been shown that the intramuscular delivery of $\alpha$-GalCer avoids iNKT cell anergy in both mice and pigs $(21,30,52,153)$, suggesting that the risk of iNKT cell hyporesponsiveness may be low if prime-boost vaccination strategies were employed with IAV vaccines using the i.m. route.

Studies that have employed inactivated IAV vaccines, viral peptides, and DNA vaccines have used a variety of immunization routes, although intramuscular injection is the most common. In contrast, iNKT-adjuvanted live attenuated IAV vaccines have mostly been delivered intranasally to induce protective immunity at the site of infection. In general, the systemic routes of vaccine and $\alpha$-GalCer co-administration globally activate iNKT cells in a way that greatly enhances neutralizing antibodies (21, $23,30)$. However, this route is not as effective as intranasal administration at inducing secretory IgA antibodies necessary for cross-protection against heterologous virus strains (23). Studies that have compared the efficacy of different vaccination sites include the report by Galli et al. which showed that the intraperitoneal, subcutaneous, intramuscular, and intravenous immunization routes were equally effective and better than intranasal administration at inducing vaccine-specific antibodies (30). Another study showed that BALB/c mice intranasally vaccinated with $\alpha$-GalCer in combination with $H A$ antigen derived either from A/PR8 (H1N1) or A/Yamagata (H1N1) were protected from subsequent infection with A/PR8 (H1N1) live virus and that the $\mathrm{A} /$ Yamagata $\mathrm{HA}$ antigen vaccine induced anti-PR8 HA IgA and IgG antibodies. In contrast, the same vaccines administered by the intramuscular route failed to induce IgA antibodies and did not provide cross-protective immunity (23). The same study compared the effect of intraperitoneally and intranasally delivered $\alpha$-GalCer on an intranasally delivered A/PR8 (H1N1) vaccine. Despite strongly activating splenic and hepatic iNKT cells, intraperitoneally delivered $\alpha$-GalCer did not induce anti-PR8 IgA and IgG antibodies as a response to the A/PR8 HA antigen vaccine administered intranasally, indicating that iNKT cell ligands must be co-administered with viral antigens to enhance an intranasally delivered vaccine (23).

The adjuvant effects of glycolipid-stimulated iNKT cells enhance immune responses to a wide variety of vaccine formats. Such versatility stems from the powerful immunoregulatory properties of iNKT cells, which affect almost every branch of the immune system and which are generally more diverse than the immunomodulatory effects induced by traditional adjuvants. A drawback of this potency is that iNKT cell responses can reduce the efficacy of live attenuated virus vaccines by inducing antiviral host responses that eliminate the weakened vaccine virus before it has had a chance to induce adaptive immunity. Consequently, it will be necessary to carefully titrate each glycolipid ligand to find a dose that increases, rather than decreases, immunity against live attenuated virus vaccines. Dosage is less important for non-attenuated vaccines, although high doses of glycolipid ligands may render iNKT cells anergic to secondary activation.

\section{POTENTIAL PITFALLS}

Several obstacles must be overcome before the immunomodulatory activities of iNKT cells can be used for human or livestock vaccines. Of paramount concern is the safety of this strategy as the potent cytokine responses generated by therapeutically activated iNKT cells can sometimes 
result in immunopathological inflammation and/or disease exacerbation (185-187). This includes reports that $\alpha$-GalCer administration can induce acute airway hyper-reactivity in mice (188), non-human primates (189), and pigs (76). In addition, the co-administration of $\alpha$-GalCer and the model antigen ovalbumin resulted in allergic airway inflammation in mice (190). These results should serve as a note of caution that combining $\alpha$-GalCer with intranasally administered IAV vaccines could cause potentially life-threatening airway inflammation. Another concern is that $\alpha$-GalCer-stimulated iNKT cells may increase the risk of vaccine-associated enhanced respiratory disease. This phenomenon occurs when inactivated IAV vaccines include a virus strain of the same hemagglutinin subtype as a subsequent challenge virus, but with substantial antigenic shift (191). This occasionally generates IgG antibodies that cross-react with the heterologous virus proteins but lack the ability to neutralize the heterologous virus effectively. These antibodies might instead bind epitopes in the HA stem region (HA2) of the heterologous virus, which facilitates infection of host cells by enhancing virus fusion activity (191). As iNKT cell activation boosts the size and the complexity of humoral responses, it is possible that they will also increase non-neutralizing antibody responses against heterologous viruses. Another concern is the potential that immunity from iNKT cell-adjuvanted vaccines will be inconsistent and unpredictable due to the high interindividual variability in iNKT cell frequency and function in genetically outbred species, including humans $(192,193)$. Indeed some studies have reported that only patients with high iNKT cell frequencies were likely to benefit from iNKT cell-based treatments $(194,195)$. It is currently difficult to predict whether an individual's iNKT cells will produce an immunogenic or tolerogenic response to stimulation, and the danger exists that iNKT cell activation might actually reduce the efficacy of IAV vaccines. This is further complicated by the phenomenon that iNKT cells undergo substantial age-related alterations in concentration and effector functions that are likely to impact their response to glycolipid antigens (196-200). Finally, it is important to consider that most studies in this field were conducted using mouse models which, although they have provided extensive knowledge about the fundamental role of iNKT cells during IAV infections, do not closely mirror humans for iNKT cell physiology. Furthermore, mice are not natural hosts of IAV infections and usually develop much more severe

\section{REFERENCES}

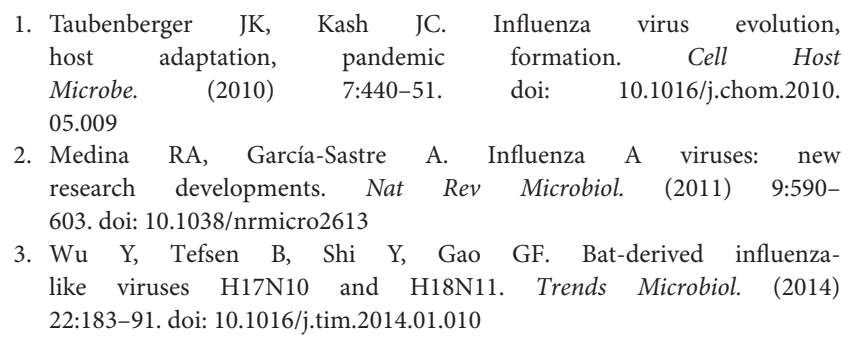

disease than humans when infected with mouse-adapted IAV strains (201). Thus, another obstacle is the need for more studies in valid preclinical animal models to translate iNKT cell-adjuvanted vaccination to the clinic.

\section{CONCLUDING REMARKS}

Durable and broadly protective IAV vaccines are greatly needed to counteract the growing threats of morbidity, mortality, and economic losses from seasonal and pandemic IAV infections. Current vaccine formulations do not provide long-lasting and cross-protective immunity, partly because they do not induce sufficient $\mathrm{T}$ cell help from virus-specific T cells. iNKT cells may help to overcome this limitation because they can be uniformly and specifically activated by therapeutic glycolipid antigens to supply a universal form of T cell help capable of expanding virusspecific antibodies and $\mathrm{CD}^{+} \mathrm{T}$ cells. Nevertheless, significant hurdles remain before the adjuvant activities of iNKT cells can be utilized in humans and livestock for vaccines against IAV and other pathogens. Future research should focus on testing this approach using preclinical animal models with high human translational potential, such as swine and non-human primates. Such studies will help determine the translatability of iNKT celladjuvanted vaccines for other respiratory diseases which have shown promise in mouse models (202).

\section{AUTHOR CONTRIBUTIONS}

JD and JR contributed to the conceptualization, writing, review, and editing. DC, WG, and BA contributed to the writing. All authors contributed to the article and approved the submitted version.

\section{FUNDING}

This work was supported by U.S. Department of Agriculture Grant 2016-09448 (to JD), National Institutes of Health Grant HD092286 (to JD and JR), the NIAID-funded Center of Excellence for Influenza Research and Surveillance (CEIRS, \#HHSN272201400006C; JR), and the U.S. Department of Homeland Security under Grant Award Number DHS-2010-ST061-AG0001 (JR) for the Center of Excellence for Emerging and Zoonotic Animal Disease (CEEZAD).
4. Kasowski EJ, Garten RJ, Bridges CB. Influenza pandemic epidemiologic and virologic diversity: reminding ourselves of the possibilities. Clin Infect Dis. (2011) 52(Suppl. 1):S44-9. doi: 10.1093/cid/ciq010

5. GBD 2017 Influenza Collaborators. Mortality, morbidity, and hospitalisations due to influenza lower respiratory tract infections, 2017: an analysis for the Global burden of disease study 2017. Lancet Respir Med. (2019) 7:69-89. doi: 10.1016/S2213-2600(18)30496-X

6. Bouvier NM, Palese P. The biology of influenza viruses. Vaccine. (2008) 26(Suppl.4):D49-53. doi: 10.1016/j.vaccine.2008.07.039

7. Kidd M. Influenza viruses: update on epidemiology, clinical features, treatment and vaccination. Curr Opin Pulm Med. (2014) 20:2426. doi: 10.1097/MCP.0000000000000049 
8. Flannery B, Kondor RJG, Chung JR, Gaglani M, Reis M, Zimmerman RK, et al. Spread of antigenically drifted Influenza A(H3N2) viruses and vaccine effectiveness in the United States during the 2018-2019 season. J Infect Dis. (2020) 221:8-15. doi: 10.1093/infdis/jiz543

9. Jackson ML, Nelson JC. The test-negative design for estimating influenza vaccine effectiveness. Vaccine. (2013) 31:21658. doi: 10.1016/j.vaccine.2013.02.053

10. Reed SG, Orr MT, Fox CB. Key roles of adjuvants in modern vaccines. Nat Med. (2013) 19:1597-608. doi: 10.1038/nm.3409

11. Henriksen-Lacey M, Christensen D, Bramwell VW, Lindenstrøm T, Agger EM, Andersen P, et al. Liposomal cationic charge and antigen adsorption are important properties for the efficient deposition of antigen at the injection site and ability of the vaccine to induce a CMI response. J Control Release. (2010) 145:102-8. doi: 10.1016/j.jconrel.2010.03.027

12. Maisonneuve C, Bertholet S, Philpott DJ, de Gregorio E. Unleashing the potential of NOD- and toll-like agonists as vaccine adjuvants. Proc Natl Acad Sci USA. (2014) 111:12294-9. doi: 10.1073/pnas.1400478111

13. Van Reeth K, Van Gucht S, Pensaert M. Investigations of the efficacy of European H1N1- and H3N2-based swine influenza vaccines against the novel H1N2 subtype. Vet Rec. (2003) 153:9-13. doi: 10.1136/vr.153.1.9

14. Godfrey DI, Uldrich AP, McCluskey J, Rossjohn J, Moody DB. The burgeoning family of unconventional T cells. Nat Immunol. (2015) 16:111423. doi: $10.1038 /$ ni.3298

15. Kawano T, Cui J, Koezuka Y, Toura I, Kaneko Y, Motoki $\mathrm{K}$, et al. CD1d-restricted and TCR-mediated activation of valpha14 NKT cells by glycosylceramides. Science. (1997) 278:1626-9. doi: 10.1126/science.278.5343.1626

16. Natori T, Koezuka Y, Higa T. Agelasphins, novel alpha-galactosylceramides from the marine sponge agelas-mauritianus. Tetrahedron Lett. (1993) 34:5591-2. doi: 10.1016/S0040-4039(00)73889-5

17. Carreño LJ, Kharkwal SS, Porcelli SA. Optimizing NKT cell ligands as vaccine adjuvants. Immunotherapy. (2014) 6:309-20. doi: 10.2217/imt.13.175

18. Speir M, Hermans IF, Weinkove R. Engaging natural killer $\mathrm{T}$ cells as 'universal helpers' for vaccination. Drugs. (2017) 77:1-15. doi: 10.1007/s40265-016-0675-z

19. Silk JD, Hermans IF, Gileadi U, Chong TW, Shepherd D, Salio M, et al. Utilizing the adjuvant properties of CD1d-dependent NK T cells in $\mathrm{T}$ cell-mediated immunotherapy. J Clin Invest. (2004) 114:180011. doi: 10.1172/JCI200422046

20. Cerundolo V, Silk JD, Masri SH, Salio M. Harnessing invariant NKT cells in vaccination strategies. Nat Rev Immunol. (2009) 9:28-38. doi: 10.1038/nri2451

21. Fotouhi F, Shaffifar M, Farahmand B, Shirian S, Saeidi M, Tabarraei A, et al. Adjuvant use of the NKT cell agonist alpha-galactosylceramide leads to enhancement of M2-based DNA vaccine immunogenicity and protective immunity against influenza A virus. Arch Virol. (2017) 162:125160. doi: 10.1007/s00705-017-3230-7

22. Youn HJ, Ko SY, Lee KA, Ko HJ, Lee YS, Fujihashi K, et al. A single intranasal immunization with inactivated influenza virus and alpha-galactosylceramide induces long-term protective immunity without redirecting antigen to the central nervous system. Vaccine. (2007) 25:518998. doi: 10.1016/j.vaccine.2007.04.081

23. Kamijuku H, Nagata Y, Jiang X, Ichinohe T, Tashiro T, Mori K, et al. Mechanism of NKT cell activation by intranasal coadministration of alphagalactosylceramide, which can induce cross-protection against influenza viruses. Mucosal Immunol. (2008) 1:208-18. doi: 10.1038/mi.2008.2

24. Guillonneau C, Mintern JD, Hubert FX, Hurt AC, Besra GS, Porcelli S, et al. Combined NKT cell activation and influenza virus vaccination boosts memory CTL generation and protective immunity. Proc Natl Acad Sci USA. (2009) 106:3330-5. doi: 10.1073/pnas.0813309106

25. Li K, Luo J, Wang C, He H. $\alpha$-Galactosylceramide potently augments M2e-induced protective immunity against highly pathogenic $\mathrm{H} 5 \mathrm{~N} 1$ avian influenza virus infection in mice. Vaccine. (2011) 29:7711-7. doi: 10.1016/j.vaccine.2011.07.136

26. Ko SY, Ko HJ, Chang WS, Park SH, Kweon MN, Kang CY. alphaGalactosylceramide can act as a nasal vaccine adjuvant inducing protective immune responses against viral infection and tumor. J Immunol. (2005) 175:3309-17. doi: 10.4049/jimmunol.175.5.3309
27. Kopecky-Bromberg SA, Fraser KA, Pica N, Carnero E, Moran TM, Franck RW, et al. Alpha-C-galactosylceramide as an adjuvant for a live attenuated influenza virus vaccine. Vaccine. (2009) 27:376674. doi: 10.1016/j.vaccine.2009.03.090

28. Anderson RJ, Li J, Kedzierski L, Compton BJ, Hayman CM, Osmond TL, et al. Augmenting influenza-specific $\mathrm{T}$ cell memory generation with a natural killer T cell-dependent glycolipid-peptide vaccine. ACS Chem Biol. (2017) 12:2898-905. doi: 10.1021/acschembio.7b00845

29. Yamasaki S, Shimizu K, Kometani K, Sakurai M, Kawamura M, Fujii SI. In vivo dendritic cell targeting cellular vaccine induces CD4. Sci Rep. (2016) 6:35173. doi: 10.1038/srep35173

30. Galli G, Pittoni P, Tonti E, Malzone C, Uematsu Y, Tortoli M, et al. Invariant NKT cells sustain specific B cell responses and memory. Proc Natl Acad Sci USA. (2007) 104:3984-9. doi: 10.1073/pnas.0700191104

31. Hung JT, Tsai YC, Lin WD, Jan JT, Lin KH, Huang JR, et al. Potent adjuvant effects of novel NKT stimulatory glycolipids on hemagglutinin based DNA vaccine for H5N1 influenza virus. Antiviral Res. (2014) 107:1108. doi: 10.1016/j.antiviral.2014.04.007

32. Lee YS, Lee KA, Lee JY, Kang MH, Song YC, Baek DJ, et al. An $\alpha$-GalCer analogue with branched acyl chain enhances protective immune responses in a nasal influenza vaccine. Vaccine. (2011) 29:41725. doi: 10.1016/j.vaccine.2010.11.005

33. Feng H, Nakajima N, Wu L, Yamashita M, Lopes TJS, Tsuji M, et al. A glycolipid adjuvant, 7DW8-5, enhances the protective immune response to the current split influenza vaccine in mice. Front Microbiol. (2019) 10:2157. doi: 10.3389/fmicb.2019.02157

34. Makino Y, Kanno R, Ito T, Higashino K, Taniguchi M. Predominant expression of invariant $\mathrm{V}$ alpha $14+\mathrm{TCR}$ alpha chain in NK1.1+ T cell populations. Int Immunol. (1995) 7:1157-61. doi: 10.1093/intimm/7.7.1157

35. Budd RC, Miescher GC, Howe RC, Lees RK, Bron C, MacDonald HR. Developmentally regulated expression of $\mathrm{T}$ cell receptor beta chain variable domains in immature thymocytes. J Exp Med. (1987) 166:57782. doi: $10.1084 /$ jem.166.2.577

36. Fowlkes BJ, Kruisbeek AM, Ton-That H, Weston MA, Coligan JE, Schwartz $\mathrm{RH}$, et al. A novel population of T-cell receptor alpha beta-bearing thymocytes which predominantly expresses a single $\mathrm{V}$ beta gene family. Nature. (1987) 329:251-4. doi: 10.1038/329251a0

37. Ceredig R, Lynch F, Newman P. Phenotypic properties, interleukin 2 production, and developmental origin of a "mature" subpopulation of Lyt2- L3T4- mouse thymocytes. Proc Natl Acad Sci USA. (1987) 84:857882. doi: $10.1073 /$ pnas.84.23.8578

38. Sykes $\mathrm{M}$. Unusual $\mathrm{T}$ cell populations in adult murine bone marrow. Prevalence of CD3+CD4-CD8- and alpha beta TCR+NK1.1+ cells. J Immunol. (1990) 145:3209-15.

39. Lantz $\mathrm{O}$, Bendelac A. An invariant $\mathrm{T}$ cell receptor alpha chain is used by a unique subset of major histocompatibility complex class I-specific CD4+ and CD4-8- T cells in mice and humans. J Exp Med. (1994) 180:10976. doi: 10.1084/jem.180.3.1097

40. Moodycliffe AM, Maiti S, Ullrich SE. Splenic NK1.1-negative, TCR alpha beta intermediate $\mathrm{CD} 4+\mathrm{T}$ cells exist in naive NK1.1 allelic positive and negative mice, with the capacity to rapidly secrete large amounts of IL-4 and IFN-gamma upon primary TCR stimulation. I Immunol. (1999) 162:5156-63.

41. Bendelac A, Lantz O, Quimby ME, Yewdell JW, Bennink JR, Brutkiewicz RR. CD1 recognition by mouse NK1+ T lymphocytes. Science. (1995) 268:863-5. doi: 10.1126/science.7538697

42. Mattner J, Debord KL, Ismail N, Goff RD, Cantu C, Zhou D, et al. Exogenous and endogenous glycolipid antigens activate NKT cells during microbial infections. Nature. (2005) 434:525-9. doi: 10.1038/nature03408

43. Rossjohn J, Pellicci DG, Patel O, Gapin L, Godfrey DI. Recognition of CD1d-restricted antigens by natural killer T cells. Nat Rev Immunol. (2012) 12:845-57. doi: 10.1038/nri3328

44. Benlagha $\mathrm{K}$, Weiss $\mathrm{A}$, Beavis $\mathrm{A}$, Teyton $\mathrm{L}$, Bendelac $\mathrm{A}$. In vivo identification of glycolipid antigen-specific $\mathrm{T}$ cells using fluorescent CD1d tetramers. J Exp Med. (2000) 191:1895-903. doi: 10.1084/jem.191.11. 1895

45. Matsuda JL, Naidenko OV, Gapin L, Nakayama T, Taniguchi M, Wang CR, et al. Tracking the response of natural killer $\mathrm{T}$ cells to a 
glycolipid antigen using CD1d tetramers. J Exp Med. (2000) 192:74154. doi: 10.1084 /jem.192.5.741

46. Rhost S, Lofbom L, Rynmark BM, Pei B, Mansson JE, Teneberg S, et al. Identification of novel glycolipid ligands activating a sulfatide-reactive, CD1d-restricted, type II natural killer T lymphocyte. Eur J Immunol. (2012) 42:2851-60. doi: 10.1002/eji.201142350

47. Mempel M, Ronet C, Suarez F, Gilleron M, Puzo G, Van Kaer L, et al. Natural killer T cells restricted by the monomorphic MHC class $1 \mathrm{~b}$ CD1d1 molecules behave like inflammatory cells. J Immunol. (2002) 168:36571. doi: 10.4049 /jimmunol.168.1.365

48. Fischer K, Scotet E, Niemeyer M, Koebernick H, Zerrahn J, Maillet S, et al. Mycobacterial phosphatidylinositol mannoside is a natural antigen for CD1d-restricted T cells. Proc Natl Acad Sci USA. (2004) 101:1068590. doi: 10.1073/pnas.0403787101

49. Amprey JL, Im JS, Turco SJ, Murray HW, Illarionov PA, Besra GS, et al. A subset of liver NKT cells is activated during Leishmania donovani infection by CD1d-bound lipophosphoglycan. J Exp Med. (2004) 200:895904. doi: 10.1084/jem. 20040704

50. Schofield L, McConville MJ, Hansen D, Campbell AS, Fraser-Reid B, Grusby MJ, et al. CD1d-restricted immunoglobulin G formation to GPIanchored antigens mediated by NKT cells. Science. (1999) 283:2259. doi: $10.1126 /$ science.283.5399.225

51. Liu Y, Goff RD, Zhou D, Mattner J, Sullivan BA, Khurana A, et al. A modified alpha-galactosyl ceramide for staining and stimulating natural killer $\mathrm{T}$ cells. J Immunol Methods. (2006) 312:34-9. doi: 10.1016/j.jim.2006.02.009

52. Artiaga BL, Whitener RL, Staples CR, Driver JP. Adjuvant effects of therapeutic glycolipids administered to a cohort of NKT cell-diverse pigs. Vet Immunol Immunopathol. (2014) 162:1-13. doi: 10.1016/j.vetimm.2014.09.006

53. Kobayashi E, Motoki K, Uchida T, Fukushima H, Koezuka Y. KRN7000, a novel immunomodulator, and its antitumor activities. Oncol Res. (1995) 7:529-34.

54. Gumperz JE, Miyake S, Yamamura T, Brenner MB. Functionally distinct subsets of CD1d-restricted natural killer $\mathrm{T}$ cells revealed by $\mathrm{CD} 1 \mathrm{~d}$ tetramer staining. J Exp Med. (2002) 195:625-36. doi: 10.1084/jem.200 11786

55. Coquet JM, Chakravarti S, Kyparissoudis K, McNab FW, Pitt LA, McKenzie BS, et al. Diverse cytokine production by NKT cell subsets and identification of an IL-17-producing CD4-NK1.1- NKT cell population. Proc Natl Acad Sci USA. (2008) 105:11287-92. doi: 10.1073/pnas.0801631105

56. Lee YJ, Wang H, Starrett GJ, Phuong V, Jameson SC, Hogquist KA. Tissue-specific distribution of iNKT cells impacts their cytokine response. Immunity. (2015) 43:566-78. doi: 10.1016/j.immuni.2015.06.025

57. Goto M, Murakawa M, Kadoshima-Yamaoka K, Tanaka Y, Nagahira K, Fukuda Y, et al. Murine NKT cells produce Th17 cytokine interleukin-22. Cell Immunol. (2009) 254:81-4. doi: 10.1016/j.cellimm.2008.10.002

58. Chang YJ, Huang JR, Tsai YC, Hung JT, Wu D, Fujio M, et al. Potent immune-modulating and anticancer effects of NKT cell stimulatory glycolipids. Proc Natl Acad Sci USA. (2007) 104:10299-304. doi: 10.1073/pnas.0703824104

59. Kim JH, Chung DH. CD1d-restricted IFN- $\gamma$-secreting NKT cells promote immune complex-induced acute lung injury by regulating macrophage-inflammatory protein-1 $\alpha$ production and activation of macrophages and dendritic cells. J Immunol. (2011) 186:1432-41. doi: 10.4049/jimmunol.1003140

60. Bilenki L, Yang J, Fan Y, Wang S, Yang X. Natural killer T cells contribute to airway eosinophilic inflammation induced by ragweed through enhanced IL-4 and eotaxin production. Eur J Immunol. (2004) 34:34554. doi: 10.1002/eji.200324303

61. Faunce DE, Stein-Streilein J. NKT cell-derived RANTES recruits APCs and $\mathrm{CD} 8+\mathrm{T}$ cells to the spleen during the generation of regulatory $\mathrm{T}$ cells in tolerance. J Immunol. (2002) 169:31-8. doi: 10.4049/jimmunol. 169.1.31

62. Ohteki T, MacDonald HR. Stringent $\mathrm{V}$ beta requirement for the development of NK1.1+ T cell receptor-alpha/beta+ cells in mouse liver. J Exp Med. (1996) 183:1277-82. doi: 10.1084/jem.183.3.1277

63. Arase H, Arase N, Ogasawara K, Good RA, Onoé K. An NK1.1+ CD4+8single-positive thymocyte subpopulation that expresses a highly skewed
T-cell antigen receptor V beta family. Proc Natl Acad Sci USA. (1992) 89:6506-10. doi: 10.1073/pnas.89.14.6506

64. Matsuura A, Kinebuchi M, Chen HZ, Katabami S, Shimizu T, Hashimoto $\mathrm{Y}$, et al. NKT cells in the rat: organ-specific distribution of NKT cells expressing distinct V alpha 14 chains. J Immunol. (2000) 164:31408. doi: 10.4049/jimmunol.164.6.3140

65. Exley M, Garcia J, Balk SP, Porcelli S. Requirements for CD1d recognition by human invariant Valpha24+ CD4-CD8- T cells. J Exp Med. (1997) 186:109-20. doi: 10.1084/jem.186.1.109

66. Dellabona P, Padovan E, Casorati G, Brockhaus M, Lanzavecchia A. An invariant $\mathrm{V}$ alpha $24-\mathrm{J}$ alpha $\mathrm{Q} / \mathrm{V}$ beta $11 \mathrm{~T}$ cell receptor is expressed in all individuals by clonally expanded CD4-8- T cells. J Exp Med. (1994) 180:1171-6. doi: 10.1084/jem.180.3.1171

67. Yang G, Artiaga BL, Lomelino CL, Jayaprakash AD, Sachidanandam R, Mckenna R, et al. Next generation sequencing of the pig $\alpha \beta$ TCR repertoire identifies the porcine invariant NKT cell receptor. J Immunol. (2019) 202:1981-91. doi: 10.4049/jimmunol.1801171

68. Yang G, Artiaga BL, Lewis ST, Driver JP. Characterizing porcine invariant natural killer T cells: a comparative study with NK cells and T cells. Dev Comp Immunol. (2017) 76:343-51. doi: 10.1016/j.dci.2017.07.006

69. Pyz E, Naidenko O, Miyake S, Yamamura T, Berberich I, Cardell S, et al. The complementarity determining region 2 of BV8S2 ( $\mathrm{V}$ beta 8.2) contributes to antigen recognition by rat invariant NKT cell TCR. J Immunol. (2006) 176:7447-55. doi: 10.4049/jimmunol.176.12.7447

70. Brossay L, Chioda M, Burdin N, Koezuka Y, Casorati G, Dellabona P, et al. CD1d-mediated recognition of an alpha-galactosylceramide by natural killer $\mathrm{T}$ cells is highly conserved through mammalian evolution. J Exp Med. (1998) 188:1521-8. doi: 10.1084/jem.188.8.1521

71. Spada FM, Koezuka Y, Porcelli SA. CD1d-restricted recognition of synthetic glycolipid antigens by human natural killer T cells. J Exp Med. (1998) 188:1529-34. doi: 10.1084/jem.188.8.1529

72. Fernandez CS, Jegaskanda S, Godfrey DI, Kent SJ. In-vivo stimulation of macaque natural killer $\mathrm{T}$ cells with $\alpha$-galactosylceramide. Clin Exp Immunol. (2013) 173:480-92. doi: 10.1111/cei.12132

73. Motsinger A, Azimzadeh A, Stanic AK, Johnson RP, Van Kaer $\mathrm{L}$, Joyce $\mathrm{S}$, et al. Identification and simian immunodeficiency virus infection of CD1d-restricted macaque natural killer $\mathrm{T}$ cells. J Virol. (2003) 77:8153-8. doi: 10.1128/JVI.77.14.8153-8158. 2003

74. Fichtner AS, Paletta D, Starick L, Schumann RF, Niewiesk S, Herrmann T. Function and expression of CD1d and invariant natural killer T-cell receptor in the cotton rat (Sigmodon hispidus). Immunology. (2015) 146:61829. doi: $10.1111 / \mathrm{imm} .12532$

75. Thierry A, Robin A, Giraud S, Minouflet S, Barra A, Bridoux F, et al. Identification of invariant natural killer $\mathrm{T}$ cells in porcine peripheral blood. Vet Immunol Immunopathol. (2012) 149:272-9. doi: 10.1016/j.vetimm.2012. 06.023

76. Renukaradhya GJ, Manickam C, Khatri M, Rauf A, Li X, Tsuji M, et al. Functional invariant NKT cells in pig lungs regulate the airway hyperreactivity: a potential animal model. J Clin Immunol. (2011) 31:22839. doi: 10.1007/s10875-010-9476-4

77. Yasuda N, Masuda K, Tsukui T, Teng A, Ishii Y. Identification of canine natural $\mathrm{CD} 3$-positive $\mathrm{T}$ cells expressing an invariant $\mathrm{T}$-cell receptor alpha chain. Vet Immunol Immunopathol. (2009) 132:22431. doi: 10.1016/j.vetimm.2009.08.002

78. Looringh van Beeck FA, Reinink P, Hermsen R, Zajonc DM, Laven MJ, Fun A, Troskie M, et al. Functional CD1d and/or NKT cell invariant chain transcript in horse, pig, African elephant and guinea pig, but not in ruminants. Mol Immunol. (2009) 46:1424-31. doi: 10.1016/j.molimm.2008.12.009

79. Van Rhijn I, Koets AP, Im JS, Piebes D, Reddington F, Besra GS, Porcelli SA, et al. The bovine CD1 family contains group 1 CD1 proteins, but no functional CD1d. J Immunol. (2006) 176:4888-93. doi: 10.4049/jimmunol.176.8.4888

80. Nguyen TK, Koets AP, Vordermeier M, Jervis PJ, Cox LR, Graham SP, et al. The bovine CD1D gene has an unusual gene structure and is expressed but cannot present alpha-galactosylceramide with a C26 fatty acid. Int Immunol. (2013) 25:91-8. doi: 10.1093/intimm/dxs092 
81. Wang J, Guillaume J, Pauwels N, Van Calenbergh S, Van Rhijn I, Zajonc DM. Crystal structures of bovine CD1d reveal altered alphaGalCer presentation and a restricted A' pocket unable to bind long-chain glycolipids. PLoS ONE. (2012) 7:e47989. doi: 10.1371/journal.pone.0047989

82. Dossa RG, Alperin DC, Garzon D, Mealey RH, Brown WC, Jervis PJ, et al. In contrast to other species, alpha-Galactosylceramide (alpha-GalCer) is not an immunostimulatory NKT cell agonist in horses. Dev Comp Immunol. (2015) 49:49-58. doi: 10.1016/j.dci.2014.11.005

83. Brennan PJ, Brigl M, Brenner MB. Invariant natural killer T cells: an innate activation scheme linked to diverse effector functions. Nat Rev Immunol. (2013) 13:101-17. doi: 10.1038/nri3369

84. Brennan PJ, Tatituri RV, Brigl M, Kim EY, Tuli A, Sanderson JP, et al. Invariant natural killer $\mathrm{T}$ cells recognize lipid self antigen induced by microbial danger signals. Nat Immunol. (2011) 12:120211. doi: $10.1038 /$ ni.2143

85. Van Kaer L, Parekh VV, Wu L. Invariant natural killer $\mathrm{T}$ cells: bridging innate and adaptive immunity. Cell Tissue Res. (2011) 343:4355. doi: 10.1007/s00441-010-1023-3

86. Matsuda JL, Mallevaey T, Scott-Browne J, Gapin L. CD1d-restricted iNKT cells, the 'Swiss-Army knife' of the immune system. Curr Opin Immunol. (2008) 20:358-68. doi: 10.1016/j.coi.2008.03.018

87. Tupin E, Kinjo Y, Kronenberg M. The unique role of natural killer $\mathrm{T}$ cells in the response to microorganisms. Nat Rev Microbiol. (2007) 5:40517. doi: $10.1038 /$ nrmicro1657

88. Tyznik AJ, Tupin E, Nagarajan NA, Her MJ, Benedict CA, Kronenberg M. Cutting edge: the mechanism of invariant NKT cell responses to viral danger signals. J Immunol. (2008) 181:4452-6. doi: 10.4049/jimmunol.181. 7.4452

89. Brigl M, Bry L, Kent SC, Gumperz JE, Brenner MB. Mechanism of CD1drestricted natural killer $\mathrm{T}$ cell activation during microbial infection. Nat Immunol. (2003) 4:1230-7. doi: 10.1038/ni1002

90. Nagarajan NA, Kronenberg M. Invariant NKT cells amplify the innate immune response to lipopolysaccharide. J Immunol. (2007) 178:270613. doi: 10.4049/jimmunol.178.5.2706

91. Birkholz A, Nemčovič M, Yu ED, Girardi E, Wang J, Khurana A, et al. Lipid and carbohydrate modifications of $\alpha$-galactosylceramide differently influence mouse and human type I natural killer $\mathrm{T}$ cell activation. J Biol Chem. (2015) 290:17206-17. doi: 10.1074/jbc.M115.654814

92. Sullivan BA, Nagarajan NA, Wingender G, Wang J, Scott I, Tsuji M, et al. Mechanisms for glycolipid antigen-driven cytokine polarization by Valpha14i NKT cells. J Immunol. (2010) 184:141-53. doi: 10.4049/jimmunol.0902880

93. Carreño LJ, Riquelme EM, González PA, Espagnolle N, Riedel CA, Valitutti S, et al. T-cell antagonism by short half-life pMHC ligands can be mediated by an efficient trapping of T-cell polarization toward the APC. Proc Natl Acad Sci USA. (2010) 107:210-5. doi: 10.1073/pnas.0911258107

94. González PA, Carreño LJ, Coombs D, Mora JE, Palmieri E, Goldstein B, et al. $\mathrm{T}$ cell receptor binding kinetics required for $\mathrm{T}$ cell activation depend on the density of cognate ligand on the antigen-presenting cell. Proc Natl Acad Sci USA. (2005) 102:4824-9. doi: 10.1073/pnas.0500922102

95. Lee YJ, Holzapfel KL, Zhu J, Jameson SC, Hogquist KA. Steady-state production of IL-4 modulates immunity in mouse strains and is determined by lineage diversity of iNKT cells. Nat Immunol. (2013) 14:114654. doi: 10.1038/ni.2731

96. Yu KO, Im JS, Molano A, Dutronc Y, Illarionov PA, Forestier C, et al. Modulation of CD1d-restricted NKT cell responses by using $\mathrm{N}$-acyl variants of alpha-galactosylceramides. Proc Natl Acad Sci USA. (2005) 102:33838. doi: 10.1073/pnas.0407488102

97. Im JS, Arora P, Bricard G, Molano A, Venkataswamy MM, Baine I, et al. Kinetics and cellular site of glycolipid loading control the outcome of natural killer T cell activation. Immunity. (2009) 30:88898. doi: 10.1016/j.immuni.2009.03.022

98. Wilson MT, Johansson C, Olivares-Villagómez D, Singh AK, Stanic AK, Wang CR, et al. The response of natural killer $\mathrm{T}$ cells to glycolipid antigens is characterized by surface receptor down-modulation and expansion. Proc Natl Acad Sci USA. (2003) 100:10913-8. doi: 10.1073/pnas.1833166100

99. Crowe NY, Uldrich AP, Kyparissoudis K, Hammond KJ, Hayakawa $\mathrm{Y}$, Sidobre $\mathrm{S}$, et al. Glycolipid antigen drives rapid expansion and sustained cytokine production by NKT cells. J Immunol. (2003) 171:40207. doi: 10.4049/jimmunol.171.8.4020

100. Fujii S, Shimizu K, Kronenberg M, Steinman RM. Prolonged IFN-gammaproducing NKT response induced with alpha-galactosylceramide-loaded DCs. Nat Immunol. (2002) 3:867-74. doi: 10.1038/ni827

101. Parekh VV, Wilson MT, Olivares-Villagómez D, Singh AK, Wu L, Wang CR, et al. Glycolipid antigen induces long-term natural killer $\mathrm{T}$ cell anergy in mice. J Clin Invest. (2005) 115:2572-83. doi: 10.1172/JCI24762

102. Uldrich AP, Crowe NY, Kyparissoudis K, Pellicci DG, Zhan Y, Lew $\mathrm{AM}$, et al. NKT cell stimulation with glycolipid antigen in vivo: costimulation-dependent expansion, Bim-dependent contraction, and hyporesponsiveness to further antigenic challenge. J Immunol. (2005) 175:3092-101. doi: 10.4049/jimmunol.175.5.3092

103. Sullivan BA, Kronenberg M. Activation or anergy: NKT cells are stunned by alpha-galactosylceramide. J Clin Invest. (2005) 115:23289. doi: 10.1172/JCI26297

104. Kim S, Lalani S, Parekh VV, Vincent TL, Wu L, Van Kaer L. Impact of bacteria on the phenotype, functions, and therapeutic activities of invariant NKT cells in mice. J Clin Invest. (2008) 118:2301-15. doi: 10.1172/JCI33071

105. Chiba A, Dascher CC, Besra GS, Brenner MB. Rapid NKT cell responses are self-terminating during the course of microbial infection. J Immunol. (2008) 181:2292-302. doi: 10.4049/jimmunol.181.4.2292

106. Choi HJ, Xu H, Geng Y, Colmone A, Cho H, Wang CR. Bacterial infection alters the kinetics and function of iNKT cell responses. J Leukoc Biol. (2008) 84:1462-71. doi: 10.1189/jlb.0108038

107. Joshi SK, Lang GA, Larabee JL, Devera TS, Aye LM, Shah HB, et al. Bacillus anthracis lethal toxin disrupts TCR signaling in CD1drestricted NKT cells leading to functional anergy. PLoS Pathog. (2009) 5:e1000588. doi: 10.1371/journal.ppat.1000588

108. Raftery MJ, Winau F, Giese T, Kaufmann SH, Schaible UE, Schönrich G. Viral danger signals control CD1d de novo synthesis and NKT cell activation. Eur J Immunol. (2008) 38:668-79. doi: 10.1002/eji.200737233

109. Montoya CJ, Jie HB, Al-Harthi L, Mulder C, Patiño PJ, Rugeles MT, et al. Activation of plasmacytoid dendritic cells with TLR9 agonists initiates invariant NKT cell-mediated cross-talk with myeloid dendritic cells. $J$ Immunol. (2006) 177:1028-39. doi: 10.4049/jimmunol.177.2.1028

110. Karmakar S, Bhaumik SK, Paul J, De T. TLR4 and NKT cell synergy in immunotherapy against visceral leishmaniasis. PLoS Pathog. (2012) 8:e1002646. doi: 10.1371/journal.ppat.1002646

111. Chen T, Guo J, Han C, Yang M, Cao X. Heat shock protein 70, released from heat-stressed tumor cells, initiates antitumor immunity by inducing tumor cell chemokine production and activating dendritic cells via TLR4 pathway. J Immunol. (2009) 182:1449-59. doi: 10.4049/jimmunol.182.3.1449

112. Sharma AK, LaPar DJ, Stone ML, Zhao Y, Kron IL, Laubach VE. Receptor for advanced glycation end products (RAGE) on iNKT cells mediates lung ischemia-reperfusion injury. Am J Transplant. (2013) 13:2255-67. doi: 10.1111/ajt. 12368

113. Paget C, Mallevaey T, Speak AO, Torres D, Fontaine J, Sheehan KC, et al. Activation of invariant NKT cells by toll-like receptor 9-stimulated dendritic cells requires type I interferon and charged glycosphingolipids. Immunity. (2007) 27:597-609. doi: 10.1016/j.immuni.2007.08.017

114. Wang X, Bishop KA, Hegde S, Rodenkirch LA, Pike JW, Gumperz JE. Human invariant natural killer $\mathrm{T}$ cells acquire transient innate responsiveness via histone $\mathrm{H} 4$ acetylation induced by weak TCR stimulation. J Exp Med. (2012) 209:987-1000. doi: 10.1084/jem.2011 1024

115. Ferhat MH, Robin A, Barbier L, Thierry A, Gombert JM, Barbarin A, et al. The impact of invariant NKT cells in sterile inflammation: the possible contribution of the alarmin/cytokine IL-33. Front Immunol. (2018) 9:2308. doi: 10.3389/fimmu.2018.02308

116. Kitamura H, Iwakabe K, Yahata T, Nishimura S, Ohta A, Ohmi Y, et al. The natural killer T (NKT) cell ligand alpha-galactosylceramide demonstrates its immunopotentiating effect by inducing interleukin (IL)-12 production by dendritic cells and IL-12 receptor expression on NKT cells. J Exp Med. (1999) 189:1121-8. doi: 10.1084/jem.189.7.1121

117. Brigl M, Tatituri RV, Watts GF, Bhowruth V, Leadbetter EA, Barton N, et al. Innate and cytokine-driven signals, rather than microbial antigens, dominate 
in natural killer $\mathrm{T}$ cell activation during microbial infection. J Exp Med. (2011) 208:1163-77. doi: 10.1084/jem.20102555

118. Wesley JD, Tessmer MS, Chaukos D, Brossay L. NK cell-like behavior of Valpha14i NK T cells during MCMV infection. PLoS Pathog. (2008) 4:e1000106. doi: 10.1371/journal.ppat.1000106

119. Bendelac A, Savage PB, Teyton L. The biology of NKT cells. Annu Rev Immunol. (2007) 25:297336. doi: 10.1146/annurev.immunol.25.022106.141711

120. Bendelac. Mouse NK1+ T cells. Curr Opin Immunol. (1995) 7:36774. doi: 10.1016/0952-7915(95)80112-X

121. Kuylenstierna C, Björkström NK, Andersson SK, Sahlström P, Bosnjak L, Paquin-Proulx D, et al. NKG2D performs two functions in invariant NKT cells: direct TCR-independent activation of NK-like cytolysis and co-stimulation of activation by CD1d. Eur J Immunol. (2011) 41:191323. doi: $10.1002 /$ eji.200940278

122. Brigl $M$, Brenner MB. How invariant natural killer $\mathrm{T}$ cells respond to infection by recognizing microbial or endogenous lipid antigens. Semin Immunol. (2010) 22:79-86. doi: 10.1016/j.smim.2009.10.006

123. Salio M, Speak AO, Shepherd D, Polzella P, Illarionov PA, Veerapen N, et al. Modulation of human natural killer T cell ligands on TLR-mediated antigenpresenting cell activation. Proc Natl Acad Sci USA. (2007) 104:204905. doi: 10.1073/pnas.0710145104

124. Yang OO, Racke FK, Nguyen PT, Gausling R, Severino ME, Horton $\mathrm{HF}$, et al. CD1d on myeloid dendritic cells stimulates cytokine secretion from and cytolytic activity of $\mathrm{V}$ alpha $24 \mathrm{~J}$ alpha $\mathrm{Q} T$ cells: a feedback mechanism for immune regulation. J Immunol. (2000) 165:375662. doi: 10.4049/jimmunol.165.7.3756

125. Yoo JK, Braciale TJ. IL-21 promotes late activator APC-mediated T follicular helper cell differentiation in experimental pulmonary virus infection. PLoS ONE. (2014) 9:e105872. doi: 10.1371/journal.pone.0105872

126. Taraban VY, Martin S, Attfield KE, Glennie MJ, Elliott T, Elewaut D, et al. Invariant NKT cells promote CD8+ cytotoxic $\mathrm{T}$ cell responses by inducing CD70 expression on dendritic cells. J Immunol. (2008) 180:461520. doi: 10.4049/jimmunol.180.7.4615

127. Hermans IF, Silk JD, Gileadi U, Salio M, Mathew B, Ritter G, et al. NKT cells enhance $\mathrm{CD} 4+$ and $\mathrm{CD} 8+\mathrm{T}$ cell responses to soluble antigen in vivo through direct interaction with dendritic cells. J Immunol. (2003) 171:51407. doi: 10.4049/jimmunol.171.10.5140

128. Fujii SI, Yamasaki S, Sato Y, Shimizu K. Vaccine designs utilizing invariant NKT-licensed antigen-presenting cells provide NKT or T cell help for B cell responses. Front Immunol. (2018) 9:1267. doi: 10.3389/fimmu.2018.01267

129. Lang ML. How do natural killer T cells help B cells? Expert Rev Vaccines. (2009) 8:1109-21. doi: 10.1586/erv.09.56

130. Doherty DG, Melo AM, Moreno-Olivera A, Solomos AC. Activation and regulation of B cell responses by invariant natural killer T cells. Front Immunol. (2018) 9:1360. doi: 10.3389/fimmu.2018.01360

131. Vomhof-DeKrey EE, Yates J, Leadbetter EA. Invariant NKT cells provide innate and adaptive help for B cells. Curr Opin Immunol. (2014) 28:127. doi: 10.1016/j.coi.2014.01.007

132. Dellabona P, Abrignani S, Casorati G. iNKT-cell help to B cells: a cooperative job between innate and adaptive immune responses. Eur J Immunol. (2014) 44:2230-7. doi: 10.1002/eji.201344399

133. Barral P, Eckl-Dorna J, Harwood NE, de Santo C, Salio M, Illarionov P, et al. B cell receptor-mediated uptake of CD1d-restricted antigen augments antibody responses by recruiting invariant NKT cell help in vivo. Proc Natl Acad Sci USA. (2008) 105:8345-50. doi: 10.1073/pnas.0802968105

134. Chang PP, Barral P, Fitch J, Pratama A, Ma CS, Kallies A, et al. Identification of Bcl-6-dependent follicular helper NKT cells that provide cognate help for B cell responses. Nat Immunol. (2012) 13:35-43. doi: 10.1038/ni.2166

135. King IL, Fortier A, Tighe M, Dibble J, Watts GF, Veerapen N, et al. Invariant natural killer $\mathrm{T}$ cells direct $\mathrm{B}$ cell responses to cognate lipid antigen in an IL21-dependent manner. Nat Immunol. (2012) 13:44-50. doi: 10.1038/ni.2172

136. Leadbetter EA, Brigl M, Illarionov P, Cohen N, Luteran MC, Pillai S, et al. NK $\mathrm{T}$ cells provide lipid antigen-specific cognate help for B cells. Proc Natl Acad Sci USA. (2008) 105:8339-44. doi: 10.1073/pnas.0801375105

137. Tonti E, Galli G, Malzone C, Abrignani S, Casorati G, Dellabona P. NKTcell help to B lymphocytes can occur independently of cognate interaction. Blood. (2009) 113:370-6. doi: 10.1182/blood-2008-06-166249
138. Gray JD, Horwitz DA. Activated human NK cells can stimulate resting B cells to secrete immunoglobulin. J Immunol. (1995) 154:5656-64.

139. Gaya M, Barral P, Burbage M, Aggarwal S, Montaner B, Warren Navia A, et al. Initiation of antiviral B cell immunity relies on innate signals from spatially positioned NKT cells. Cell. (2017) 172:51733.e20. doi: 10.1016/j.cell.2017.11.036

140. Berzins SP, Cochrane AD, Pellicci DG, Smyth MJ, Godfrey DI. Limited correlation between human thymus and blood NKT cell content revealed by an ontogeny study of paired tissue samples. Eur J Immunol. (2005) 35:1399-407. doi: 10.1002/eji.200425958

141. Long HM, Chagoury OL, Leese AM, Ryan GB, James E, Morton LT, et al. MHC II tetramers visualize human CD4+ T cell responses to Epstein-Barr virus infection and demonstrate atypical kinetics of the nuclear antigen EBNA1 response. J Exp Med. (2013) 210:933-49. doi: 10.1084/jem.20121437

142. Yu KKQ, Wilburn DB, Hackney JA, Darrah PA, Foulds KE, James CA, et al. Conservation of molecular and cellular phenotypes of invariant NKT cells between humans and non-human primates. Immunogenetics. (2019) 71:465-78. doi: 10.1007/s00251-019-01118-9

143. De Santo C, Salio M, Masri SH, Lee LY, Dong T, Speak AO, et al. Invariant NKT cells reduce the immunosuppressive activity of influenza A virusinduced myeloid-derived suppressor cells in mice and humans. J Clin Invest. (2008) 118:4036-48. doi: 10.1172/JCI36264

144. Kok WL, Denney L, Benam K, Cole S, Clelland C, McMichael AJ, et al. Pivotal advance: invariant NKT cells reduce accumulation of inflammatory monocytes in the lungs and decrease immune-pathology during severe influenza A virus infection. J Leukoc Biol. (2012) 91:35768. doi: $10.1189 / \mathrm{jlb} .0411184$

145. Ishikawa H, Tanaka K, Kutsukake E, Fukui T, Sasaki H, Hata A, et al. IFN- $\gamma$ production downstream of NKT cell activation in mice infected with influenza virus enhances the cytolytic activities of both NK cells and viral antigen-specific CD8+ T cells. Virology. (2010) 407:32532. doi: $10.1016 /$ j.virol.2010.08.030

146. Paget C, Ivanov S, Fontaine J, Blanc F, Pichavant M, Renneson J, et al. Potential role of invariant NKT cells in the control of pulmonary inflammation and $\mathrm{CD} 8+\mathrm{T}$ cell response during acute influenza A virus H3N2 pneumonia. J Immunol. (2011) 186:5590602. doi: $10.4049 /$ jimmunol.1002348

147. Kulkarni RR, Haeryfar SM, Sharif S. The invariant NKT cell subset in antiviral defenses: a dark horse in anti-influenza immunity? J Leukoc Biol. (2010) 88:635-43. doi: $10.1189 / \mathrm{jlb} .0410191$

148. Ho LP, Denney L, Luhn K, Teoh D, Clelland C, McMichael AJ. Activation of invariant NKT cells enhances the innate immune response and improves the disease course in influenza A virus infection. Eur J Immunol. (2008) 38:1913-22. doi: 10.1002/eji.200738017

149. Paget C, Ivanov S, Fontaine J, Renneson J, Blanc F, Pichavant M, et al. Interleukin-22 is produced by invariant natural killer $\mathrm{T}$ lymphocytes during influenza A virus infection: potential role in protection against lung epithelial damages. J Biol Chem. (2012) 287:8816-29. doi: 10.1074/jbc.M111.304758

150. Benton KA, Misplon JA, Lo CY, Brutkiewicz RR, Prasad SA, Epstein SL. Heterosubtypic immunity to influenza A virus in mice lacking IgA, all Ig, NKT cells, or gamma delta T cells. J Immunol. (2001) 166:743745. doi: 10.4049/jimmunol.166.12.7437

151. Renu S, Dhakal S, Kim E, Goodman J, Lakshmanappa YS, Wannemuehler $\mathrm{MJ}$, et al. Intranasal delivery of influenza antigen by nanoparticles, but not NKT-cell adjuvant differentially induces the expression of Bcell activation factors in mice and swine. Cell Immunol. (2018) 329:2730. doi: 10.1016/j.cellimm.2018.04.005

152. Dwivedi V, Manickam C, Dhakal S, Binjawadagi B, Ouyang K, Hiremath J, et al. Adjuvant effects of invariant NKT cell ligand potentiates the innate and adaptive immunity to an inactivated H1N1 swine influenza virus vaccine in pigs. Vet Microbiol. (2016) 186:157-63. doi: 10.1016/j.vetmic.2016.02.028

153. Artiaga BL, Yang G, Hackmann TJ, Liu Q, Richt JA, Salek-Ardakani $S$, et al. $\alpha$-Galactosylceramide protects swine against influenza infection when administered as a vaccine adjuvant. Sci Rep. (2016) 6:23593. doi: 10.1038/srep23593

154. Lee PT, Benlagha K, Teyton L, Bendelac A. Distinct functional lineages of human V(alpha)24 natural killer T cells. J Exp Med. (2002) 195:63741. doi: $10.1084 /$ jem. 20011908 
155. Chen YG, Tsaih SW, Serreze DV. Genetic control of murine invariant natural killer T-cell development dynamically differs dependent on the examined tissue type. Genes Immun. (2012) 13:164-74. doi: 10.1038/gene.2011.68

156. Gadola SD, Dulphy N, Salio M, Cerundolo V. Valpha24-JalphaQindependent $\mathrm{V}, \mathrm{CD} 1 \mathrm{~d}$-restricted recognition of alpha-galactosylceramide by human CD4(+) and CD8alphabeta(+) T lymphocytes. J Immunol. (2002) 168:5514-20. doi: 10.4049/jimmunol.168.11.5514

157. Takahashi T, Chiba S, Nieda M, Azuma T, Ishihara S, Shibata Y, et al. Cutting edge: analysis of human V alpha $24+\mathrm{CD} 8+\mathrm{NK} \mathrm{T}$ cells activated by alphagalactosylceramide-pulsed monocyte-derived dendritic cells. J Immunol. (2002) 168:3140-4. doi: 10.4049/jimmunol.168.7.3140

158. Townsend MJ, Weinmann AS, Matsuda JL, Salomon R, Farnham PJ, Biron CA, et al. T-bet regulates the terminal maturation and homeostasis of NK and Valpha14i NKT cells. Immunity. (2004) 20:47794. doi: 10.1016/S1074-7613(04)00076-7

159. Engel I, Seumois G, Chavez L, Samaniego-Castruita D, White B, Chawla $\mathrm{A}$, et al. Innate-like functions of natural killer $\mathrm{T}$ cell subsets result from highly divergent gene programs. Nat Immunol. (2016) 17:72839. doi: 10.1038/ni.3437

160. Georgiev H, Ravens I, Benarafa C, Förster R, Bernhardt G. Distinct gene expression patterns correlate with developmental and functional traits of iNKT subsets. Nat Commun. (2016) 7:13116. doi: 10.1038/ncomms13116

161. Lee YJ, Starrett GJ, Lee ST, Yang R, Henzler CM, Jameson SC, et al. Lineage-specific effector signatures of invariant NKT cells are shared amongst $\gamma \delta$ T, innate lymphoid, Th cells. J Immunol. (2016) 197:146070. doi: 10.4049/jimmunol.1600643

162. Constantinides MG, Bendelac A. Transcriptional regulation of the NKT cell lineage. Curr Opin Immunol. (2013) 25:161-7. doi: 10.1016/j.coi.2013.01.003

163. Kim PJ, Pai SY, Brigl M, Besra GS, Gumperz J, Ho IC. GATA-3 regulates the development and function of invariant NKT cells. J Immunol. (2006) 177:6650-9. doi: 10.4049/jimmunol.177.10.6650

164. Doisne JM, Becourt C, Amniai L, Duarte N, Le Luduec JB, Eberl G, et al. Skin and peripheral lymph node invariant NKT cells are mainly retinoic acid receptor-related orphan receptor (gamma)t+ and respond preferentially under inflammatory conditions. J Immunol. (2009) 183:21429. doi: 10.4049/jimmunol.0901059

165. Jaiswal AK, Sadasivam M, Hamad ARA. Syndecan-1-coating of interleukin-17-producing natural killer $\mathrm{T}$ cells provides a specific method for their visualization and analysis. World J Diabetes. (2017) 8:130-4. doi: 10.4239/wjd.v8.i4.130

166. Lynch L, Michelet X, Zhang S, Brennan PJ, Moseman A, Lester C, et al. Regulatory iNKT cells lack expression of the transcription factor PLZF and control the homeostasis of T(reg) cells and macrophages in adipose tissue. Nat Immunol. (2015) 16:85-95. doi: 10.1038/ni.3047

167. Wingender G, Sag D, Kronenberg M. NKT10 cells: a novel iNKT cell subset. Oncotarget. (2015) 6:26552-3. doi: 10.18632/oncotarget. 5270

168. Savage AK, Constantinides MG, Han J, Picard D, Martin E, Li B, et al. The transcription factor PLZF directs the effector program of the NKT cell lineage. Immunity. (2008) 29:391-403. doi: 10.1016/j.immuni.2008. 07.011

169. Kovalovsky D, Uche OU, Eladad S, Hobbs RM, Yi W, Alonzo E, et al. The BTB-zinc finger transcriptional regulator PLZF controls the development of invariant natural killer T cell effector functions. Nat Immunol. (2008) 9:1055-64. doi: 10.1038/ni.1641

170. Kovalovsky D, Alonzo ES, Uche OU, Eidson M, Nichols KE, Sant'Angelo DB. PLZF induces the spontaneous acquisition of memory/effector functions in T cells independently of NKT cell-related signals. J Immunol. (2010) 184:6746-55. doi: 10.4049/jimmunol.1000776

171. Crosby CM, Kronenberg M. Tissue-specific functions of invariant natural killer $\mathrm{T}$ cells. Nat Rev Immunol. (2018) 18:559-74. doi: 10.1038/s41577-018-0034-2

172. Wolf BJ, Choi JE, Exley MA. Novel approaches to exploiting invariant NKT cells in cancer immunotherapy. Front Immunol. (2018) 9:384. doi: 10.3389/fimmu.2018.00384

173. Miyamoto K, Miyake S, Yamamura T. A synthetic glycolipid prevents autoimmune encephalomyelitis by inducing TH2 bias of natural killer T cells. Nature. (2001) 413:531-4. doi: 10.1038/35097097
174. Baev DV, Caielli S, Ronchi F, Coccia M, Facciotti F, Nichols KE, et al. Impaired SLAM-SLAM homotypic interaction between invariant NKT cells and dendritic cells affects differentiation of IL-4/IL-10-secreting NKT2 cells in nonobese diabetic mice. J Immunol. (2008) 181:86977. doi: 10.4049/jimmunol.181.2.869

175. Sag D, Krause P, Hedrick CC, Kronenberg M, Wingender G. IL-10-producing NKT10 cells are a distinct regulatory invariant NKT cell subset. J Clin Invest. (2014) 124:3725-40. doi: 10.1172/JCI72308

176. Yu KO, Porcelli SA. The diverse functions of CD1d-restricted NKT cells and their potential for immunotherapy. Immunol Lett. (2005) 100:4255. doi: 10.1016/j.imlet.2005.06.010

177. Oki S, Chiba A, Yamamura T, Miyake S. The clinical implication and molecular mechanism of preferential IL-4 production by modified glycolipid-stimulated NKT cells. J Clin Invest. (2004) 113:1631-40. doi: 10.1172/JCI200420862

178. Oki S, Tomi C, Yamamura T, Miyake S. Preferential T(h)2 polarization by $\mathrm{OCH}$ is supported by incompetent NKT cell induction of CD40L and following production of inflammatory cytokines by bystander cells in vivo. Int Immunol. (2005) 17:1619-29. doi: 10.1093/intimm/dxh342

179. McCarthy C, Shepherd D, Fleire S, Stronge VS, Koch M, Illarionov PA, et al. The length of lipids bound to human CD1d molecules modulates the affinity of NKT cell TCR and the threshold of NKT cell activation. J Exp Med. (2007) 204:1131-44. doi: 10.1084/jem.20062342

180. Schmieg J, Yang G, Franck RW, Tsuji M. Superior protection against malaria and melanoma metastases by a C-glycoside analogue of the natural killer T cell ligand alpha-Galactosylceramide. J Exp Med. (2003) 198:163141. doi: 10.1084/jem.20031192

181. Wun KS, Cameron G, Patel O, Pang SS, Pellicci DG, Sullivan LC, et al. A molecular basis for the exquisite CD1d-restricted antigen specificity and functional responses of natural killer T cells. Immunity. (2011) 34:32739. doi: 10.1016/j.immuni.2011.02.001

182. Tashiro T, Sekine-Kondo E, Shigeura T, Nakagawa R, Inoue S, OmoriMiyake M, et al. Induction of Th1-biased cytokine production by alphacarba-GalCer, a neoglycolipid ligand for NKT cells. Int Immunol. (2010) 22:319-28. doi: 10.1093/intimm/dxq012

183. Li X, Fujio M, Imamura M, Wu D, Vasan S, Wong CH, et al. Design of a potent CD1d-binding NKT cell ligand as a vaccine adjuvant. Proc Natl Acad Sci USA. (2010) 107:13010-5. doi: 10.1073/pnas.1006662107

184. Lin KH, Liang JJ, Huang WI, Lin-Chu SY, Su CY, Lee YL, et al. In vivo protection provided by a synthetic new alpha-galactosyl ceramide analog against bacterial and viral infections in murine models. Antimicrob Agents Chemother. (2010) 54:4129-36. doi: 10.1128/AAC.00368-10

185. Osman Y, Kawamura T, Naito T, Takeda K, Van Kaer L, Okumura K, et al. Activation of hepatic NKT cells and subsequent liver injury following administration of alpha-galactosylceramide. Eur J Immunol. (2000) 30:191928. doi: 10.1002/1521-4141(200007)30:7<1919::AID-IMMU1919>3.0. $\mathrm{CO} ; 2-3$

186. Kim HY, Kim S, Chung DH. FcgammaRIII engagement provides activating signals to NKT cells in antibody-induced joint inflammation. J Clin Invest. (2006) 116:2484-92. doi: 10.1172/JCI27219

187. Miellot-Gafsou A, Biton J, Bourgeois E, Herbelin A, Boissier MC, Bessis N. Early activation of invariant natural killer $\mathrm{T}$ cells in a rheumatoid arthritis model and application to disease treatment. Immunology. (2010) 130:296306. doi: 10.1111/j.1365-2567.2009.03235.x

188. Meyer EH, Goya S, Akbari O, Berry GJ, Savage PB, Kronenberg M, et al. Glycolipid activation of invariant $\mathrm{T}$ cell receptor + NK T cells is sufficient to induce airway hyperreactivity independent of conventional CD4+ T cells. Proc Natl Acad Sci USA. (2006) 103:2782-7. doi: 10.1073/pnas.0510282103

189. Matangkasombut P, Pichavant M, Yasumi T, Hendricks C, Savage PB, Dekruyff RH, et al. Direct activation of natural killer $\mathrm{T}$ cells induces airway hyperreactivity in nonhuman primates. J Allergy Clin Immunol. (2008) 121:1287-9. doi: 10.1016/j.jaci.2008.02.006

190. Kim JO, Kim DH, Chang WS, Hong C, Park SH, Kim S, et al. Asthma is induced by intranasal coadministration of allergen and natural killer Tcell ligand in a mouse model. J Allergy Clin Immunol. (2004) 114:13328. doi: 10.1016/j.jaci.2004.09.004

191. Khurana S, Loving CL, Manischewitz J, King LR, Gauger PC, Henningson $\mathrm{J}$, et al. Vaccine-induced anti-HA2 antibodies promote virus fusion 
and enhance influenza virus respiratory disease. Sci Transl Med. (2013) 5:200ra114. doi: 10.1126/scitranslmed.3006366

192. Rymarchyk SL, Lowenstein H, Mayette J, Foster SR, Damby DE, Howe IW, et al. Widespread natural variation in murine natural killer T-cell number and function. Immunology. (2008) 125:331-43. doi: 10.1111/j.1365-2567.2008.02846.x

193. Bernin H, Fehling H, Marggraff C, Tannich E, Lotter H. The cytokine profile of human NKT cells and PBMCs is dependent on donor sex and stimulus. Med Microbiol Immunol. (2016) 205:321-32. doi: 10.1007/s00430-016-0449-y

194. Metelitsa LS, Wu HW, Wang H, Yang Y, Warsi Z, Asgharzadeh S, et al. Natural killer $\mathrm{T}$ cells infiltrate neuroblastomas expressing the chemokine CCL2. J Exp Med. (2004) 199:1213-21. doi: 10.1084/jem.20031462

195. Schneiders FL, de Bruin RC, van den Eertwegh AJ, Scheper RJ, Leemans $\mathrm{CR}$, Brakenhoff $\mathrm{RH}$, et al. Circulating invariant natural killer T-cell numbers predict outcome in head and neck squamous cell carcinoma: updated analysis with 10-year follow-up. J Clin Oncol. (2012) 30:56770. doi: 10.1200/JCO.2011.38.8819

196. DelaRosa O, Tarazona R, Casado JG, Alonso C, Ostos B, Peña J, et al. Valpha24+ NKT cells are decreased in elderly humans. Exp Gerontol. (2002) 37:213-7. doi: 10.1016/S0531-5565(01)00186-3

197. Tsukahara A, Seki S, Iiai T, Moroda T, Watanabe H, Suzuki S, et al. Mouse liver T cells: their change with aging and in comparison with peripheral $\mathrm{T}$ cells. Hepatology. (1997) 26:301-9. doi: 10.1002/hep.510260208

198. Faunce DE, Palmer JL, Paskowicz KK, Witte PL, Kovacs EJ. CD1drestricted NKT cells contribute to the age-associated decline of $\mathrm{T}$ cell immunity. J Immunol. (2005) 175:3102-9. doi: 10.4049/jimmunol.175. 5.3102
199. Mocchegiani E, Giacconi R, Cipriano C, Gasparini N, Bernardini G, Malavolta $\mathrm{M}$, et al. The variations during the circadian cycle of liver CD1dunrestricted NK1.1+TCR gamma/delta+ cells lead to successful ageing. Role of metallothionein/IL-6/gp130/PARP-1 interplay in very old mice. Exp Gerontol. (2004) 39:775-88. doi: 10.1016/j.exger.2004.01.014

200. Mocchegiani E, Giacconi R, Muti E, Rogo C, Bracci M, Muzzioli M, et al. Zinc, immune plasticity, aging, and successful aging: role of metallothionein. Ann NY Acad Sci. (2004) 1019:127-34. doi: 10.1196/annals.1297.023

201. Starbæk SMR, Brogaard L, Dawson HD, Smith AD, Heegaard PMH, Larsen LE, et al. Animal models for Influenza A virus infection incorporating the involvement of innate host defenses: enhanced translational value of the porcine model. ILAR J. (2018) 59:323-37. doi: 10.1093/ilar/ily009

202. Bai L, Deng S, Reboulet R, Mathew R, Teyton L, Savage PB, et al. Natural killer T (NKT)-B-cell interactions promote prolonged antibody responses and long-term memory to pneumococcal capsular polysaccharides. Proc Natl Acad Sci USA. (2013) 110:16097-102. doi: 10.1073/pnas.1303218110

Conflict of Interest: The authors declare that the research was conducted in the absence of any commercial or financial relationships that could be construed as a potential conflict of interest.

Copyright (c) 2020 Driver, de Carvalho Madrid, Gu, Artiaga and Richt. This is an open-access article distributed under the terms of the Creative Commons Attribution License (CC BY). The use, distribution or reproduction in other forums is permitted, provided the original author(s) and the copyright owner(s) are credited and that the original publication in this journal is cited, in accordance with accepted academic practice. No use, distribution or reproduction is permitted which does not comply with these terms. 